\title{
Managing Infrastructure OF Water and Petroleum Demand in KSA
}

\author{
Magdy Shayboub Ali Mahmoud ${ }^{1,2 \star}$, Samir Mahmud Adam Abdalla ${ }^{2}$ \\ ${ }^{1}$ Computer Science Department, Faculty of Computers and Informatics, \\ Suez Canal University, Ismaillia, 41522, Egypt. \\ magdy01sh@yahoo.com \\ http://magdy_mahmoud_ci.staff.scuegypt.edu.eg/ \\ ${ }^{2}$ Computer Science Department, Applied Medical Sciences College, \\ Taif University, Kingdom of Saudi Arabia (KSA) \\ samiradm59@yahoo.com
}

\section{ABSTRACT}

The purpose of this paper is showing, how Geographical Information Systems (GIS ) can be used to support infrastructure planners and analyst on water and petroleum demand of a local area in the Kingdom of Saudi Arabia (KSA). The first part of this work discusses the issue of analysis, design and creating the geodatabase system of KSA land and infrastructure using Stylus Studio XML editor, describing the components of the whole system of Subareas in Saudi Arabia affecting local infrastructure planning and analyzing which include of specific area and facilities management. The second part defines the creation of the GIS application of the discussed field having the GIS functions of the infrastructure discusses the geodatabase of the application of GIS In infrastructure in Saudi Arabia districts. The third part defines the results of the statistics analysis populations in the Subareas, specify the relation between water resources and the elevations of subareas, the data of the layers of roads, railroads existing in Saudi Arabia specially in the eastern area where most petroleum s wells are found.

Using Google earth to show the elevation of the subareas and the relation with the water resources. Three groups of GIS forms was produced they are the geodatabase of the Saudi Arabia (area, subareas and main cities), water resources layers (water in land, water area and land cover), roads, railroads and elevations layers. The main contribution in the paper, discussed the infrastructure and the results of the statistics analysis populations in the subareas, specify the relation between water resources and the elevations of subareas of the data layers of roads, railroads existing in Saudi Arabia, especially in the eastern area where most petroleum's wells are found production and exploration of petroleum including the geodatabase of wells of petroleum distributed in Saudi Arabia finding the locations using Google earth map, satellites to locate the areas of producing petroleum.

Keywords: GIS ; Water in land; Water area; Railroad, Elevation; XML Schema.

\section{Council for Innovative Research}

Peer Review Research Publishing System

Journal: INTERNATIONAL JOURNAL OF COMPUTERS \& TECHNOLOGY

Vol 11, No.2

editor@cirworld.com

www.cirworld.com, member.cirworld.com 


\section{INTRODUCTION}

Saudi Arabia with an area of 2.15 million $\mathrm{km} 2$ is an arid and water deficit country, with limited fresh water-supplies. The kingdom of Saudi Arabia (KSA) is a desert like country lying within the continental zone where temperatures are high in summer and low in winter. It is also characterized by low annual rainfall and lacks perennial rivers or permanent bodies of water. The climatic conditions pose a continual challenge, as does the depletion of underground water resources. Due to an acute deficit, water has always been an extremely valuable resource and occupies the prominent and prime position among the natural resources of KSA. Although water is a renewable resource, yet its availability is extremely low and to the society. In the situation, there is a tremendous pressure on the existing water resources due to an increase in population, and the rising living standards of the civil society applied GIS in handling their relevant data [10,11, 15, 31].

\section{A. Review of the Water Resources of KSA}

The water resources in the Kingdom are divided into surface and underground deposits. Water collected through rainfall (surface water) is estimated to be about 2045 million cubic meters (MCM) per year. Depending upon rainfall, ground water is present in the basement crystalline rocks with an estimate of about 1.5 million cubic meters. The thickness of these rocks is about 500 meters. The production of the desalinated water reaches 740.52 million American Gallons daily. In the kingdom, about 1.5 million cubic meters treated Surface water is available with an estimate of about 2045 million cubic meters (MCM) per year comes from the rainfall, and is found predominantly in the west and south-west of the country. In 1985, surface water provided $10 \%$ of the kingdom's supply. While reporting on water resources [18,19, 31].

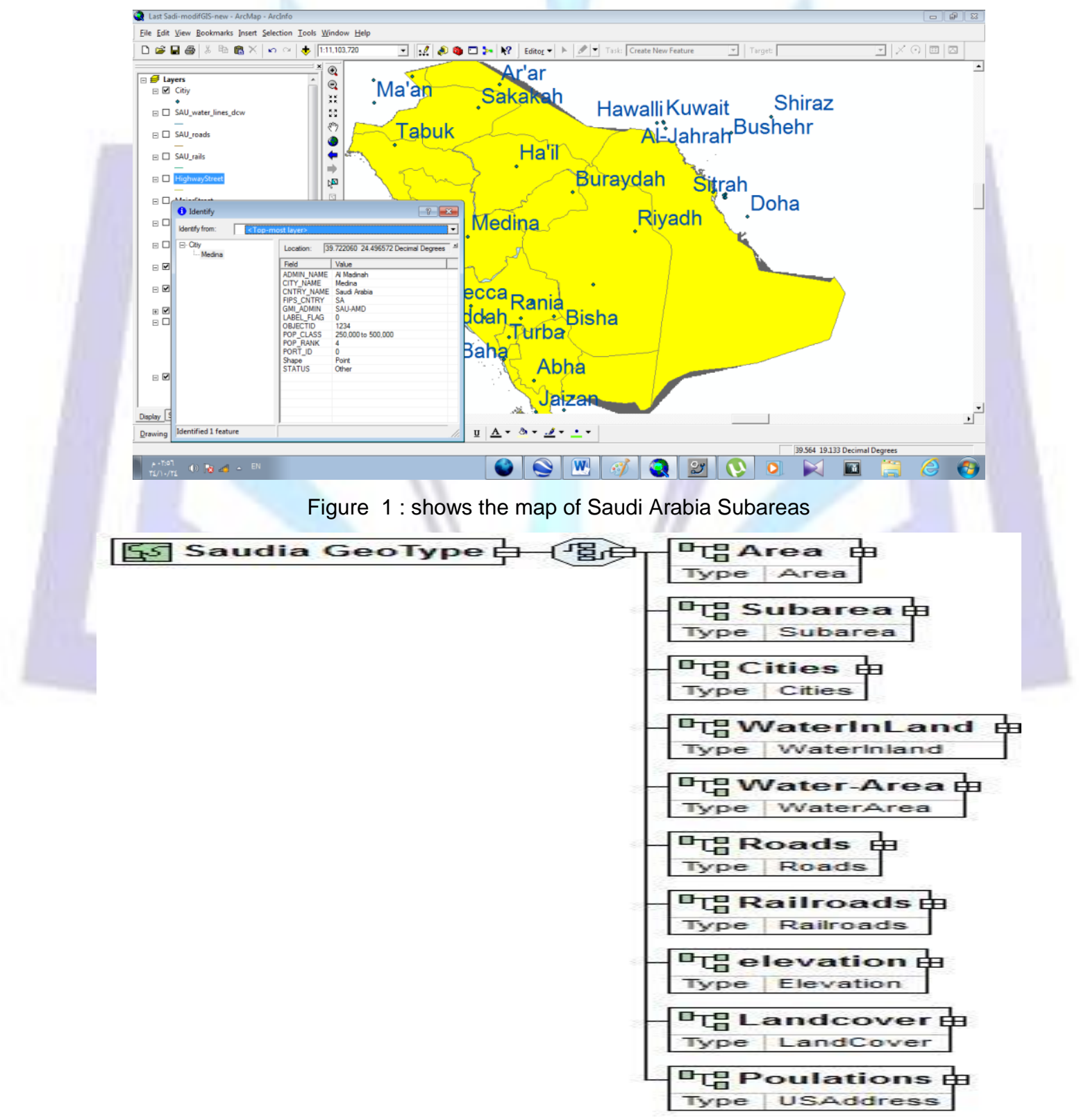

Figure 2: Shows the Diagram of Saudi Arabia Infrastructure done by XML Stylus Studio Editor 


\section{B. GIS AND INFRASTRUCTURE PLANNING}

The area of GIS and infrastructure, the collection, storage and manipulation of geographic information have undergone a revolution in recent years with the development and wide spread availability of GIS software's. Today, many Infrastructure services planners and officers can benefit from education and training in the GIS field and this will give them the chance of influencing the progress of, environmental and infrastructure assessment and the geographic allocation of infrastructure planning of a local resources locations [10-18]. The rapid adoption of GIS in the field of infrastructure planning is actually a result of the following issues:The increasing availability of geo-coded Infrastructure data that lead to having infrastructure information systems. The availability of digital geographic data at micro and/or micro scale that has several GIS coverage with enormous attribute data such as addresses land use, ownership, etc.

\section{GIS SOFTWARE'S}

GIS software such as ArcGIS 9.3 produced by Environmental Systems Research Institute (ESRI) [29-38].

become inexpensive and easier to use and runs on a wider range of platforms e.g. ,Unix, IBM.Google earth have become a very important GIS Tool visualize the earth use satellite system. The availability of spatial data analysis tools, as separate software modules or embedded is GIS .Perceived and update the base map information.Environmental, socioeconomic and other risk factors, which influence water in land and water area, under serviced, poor, inaccessible areas and other geographic and demographic factors.Population sub groups with specific needs of water recourse, roads and rail road, elevation and production and exploration of petroleum. Infrastructure services directed at land problems or risk factors for all population.Infrastructure inputs, e.g., staff, funds, capital resources, and GPS and GIS equipments used etc.Infrastructure outputs, e.g., number of client contacts, proportion of population reached for particular programmers and proportions of target population reached.Infrastructure outcomes, e.g., change in health status as a result of intervention of infrastructure services programs [1].

\section{GIS TOOLS FOR INFRASTRUCTURE PLANNING}

Saudi Arabia is the most important country in the middle east and Arab region; because of the religion areas in-side. Saudi Arabia water demand is the most factor that Governments can concentrate on giving services to their populations. Makkah region has a population of about 6.391966 persons while Riyadh has about 5.631890 persons. As shown in figure 3. GIS Tool was applied using Esri ArcGIS 9.3, ArcCatelog 9.3 was used to build the Geodatabase of Saudi Arabia Cities, subareas, high way streets, major streets in selecting this hospital. Figure 2 shows a Geodatabase in a Multi-tiered Architecture[1-10,31].

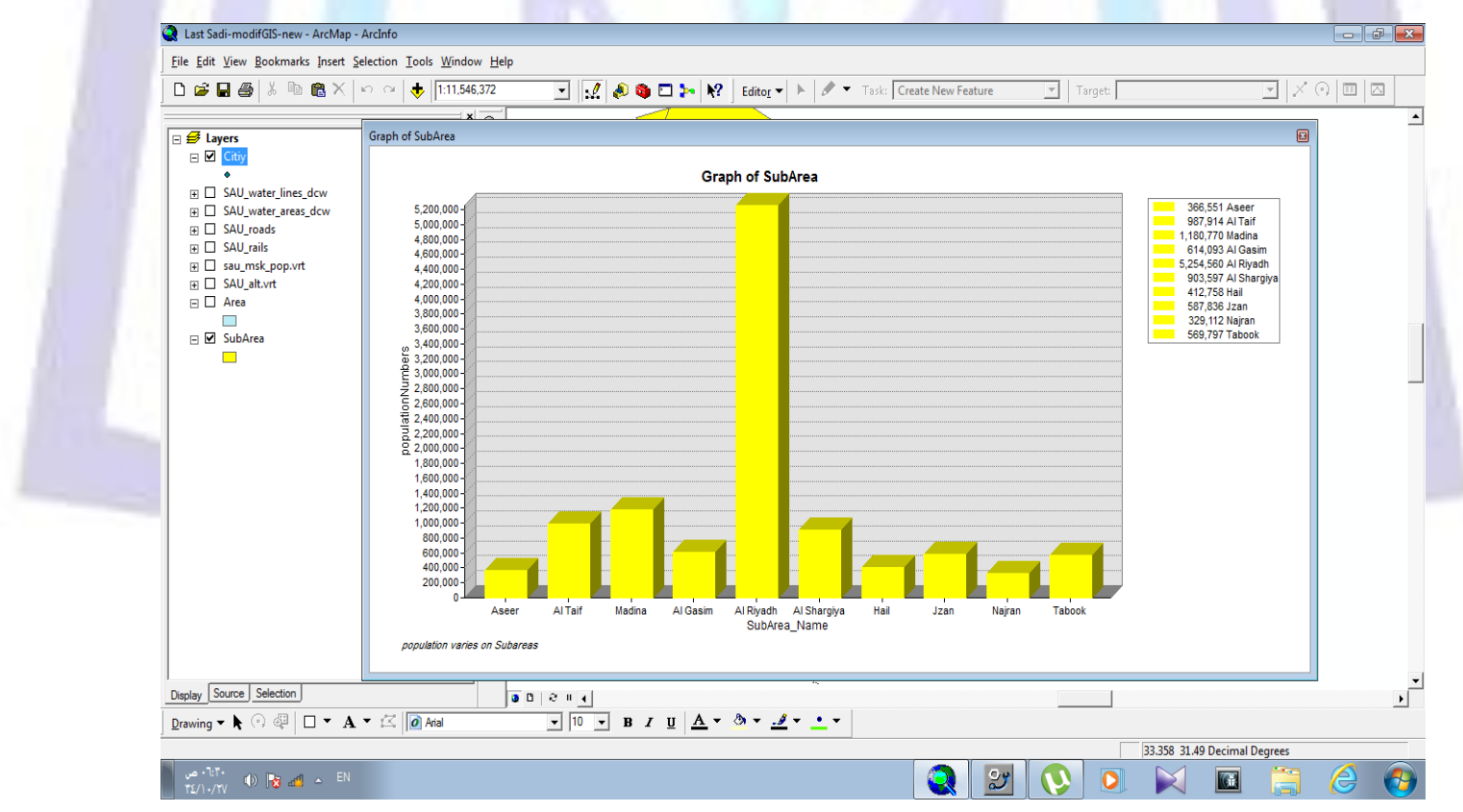

Figure 3 :Show the Populations per subarea chart.
A. XML INSTANCE REPRESENTATION OF WATER INLAND COMPLEX TYPE
$1-\langle\ldots\rangle$
2- $<$ Fid $>$ Objectld $<$ Fid $>$ [1]
3- $<$ Shape $>$ Line $</$ Shape $>$ [1] 
4- $<$ F_Code_Desc $>$ Text $</ F$ Code_Desc $>$ [1]

5- $<$ StreamName $>$ Text $</$ StreamName $>$ [1]

6- $<$ StreamLength $>$ Integer $</$ StreamLength $>$ [1]

7- $</ \ldots>$
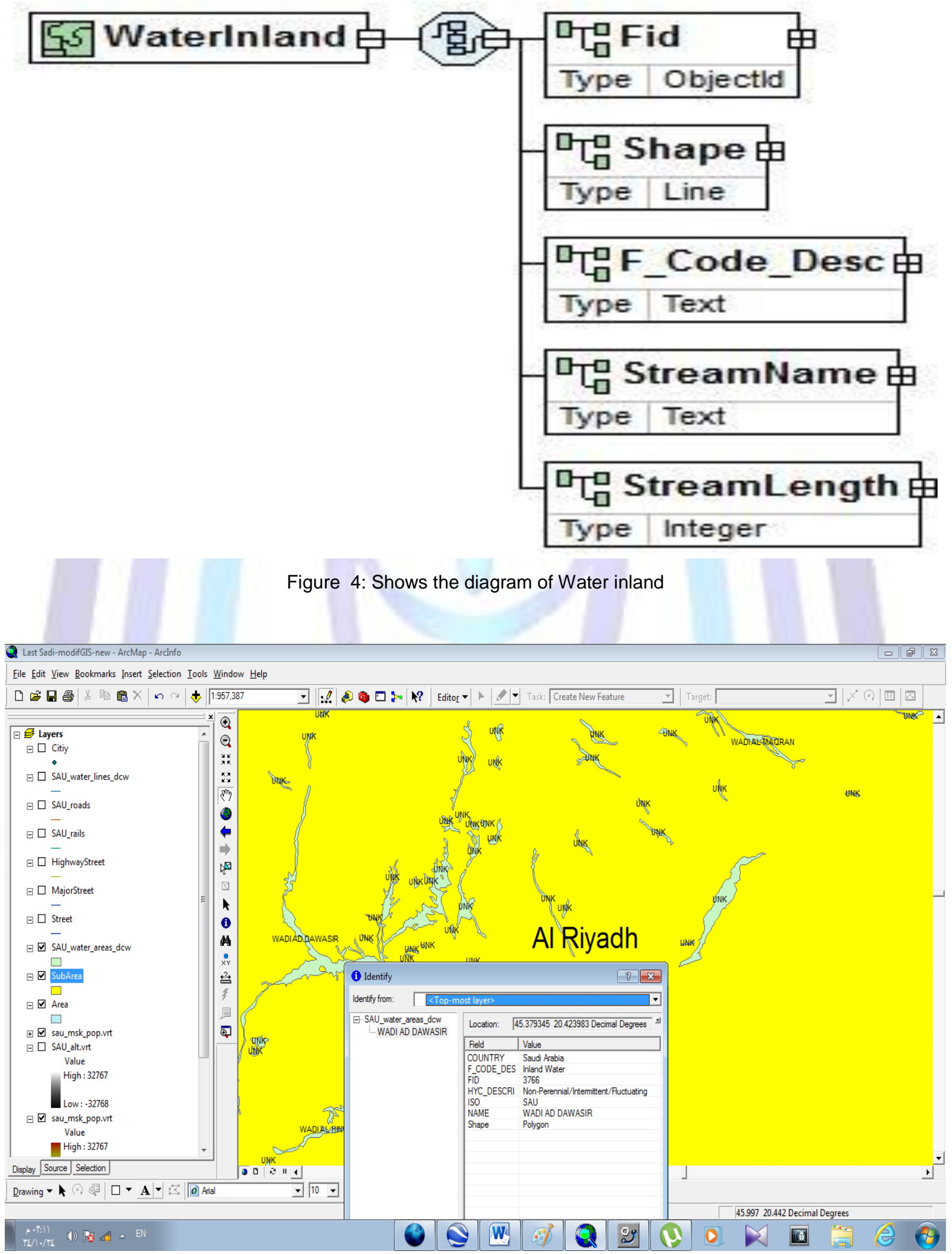

Figure 5: Shows Saudi Arabia Water in land streams 


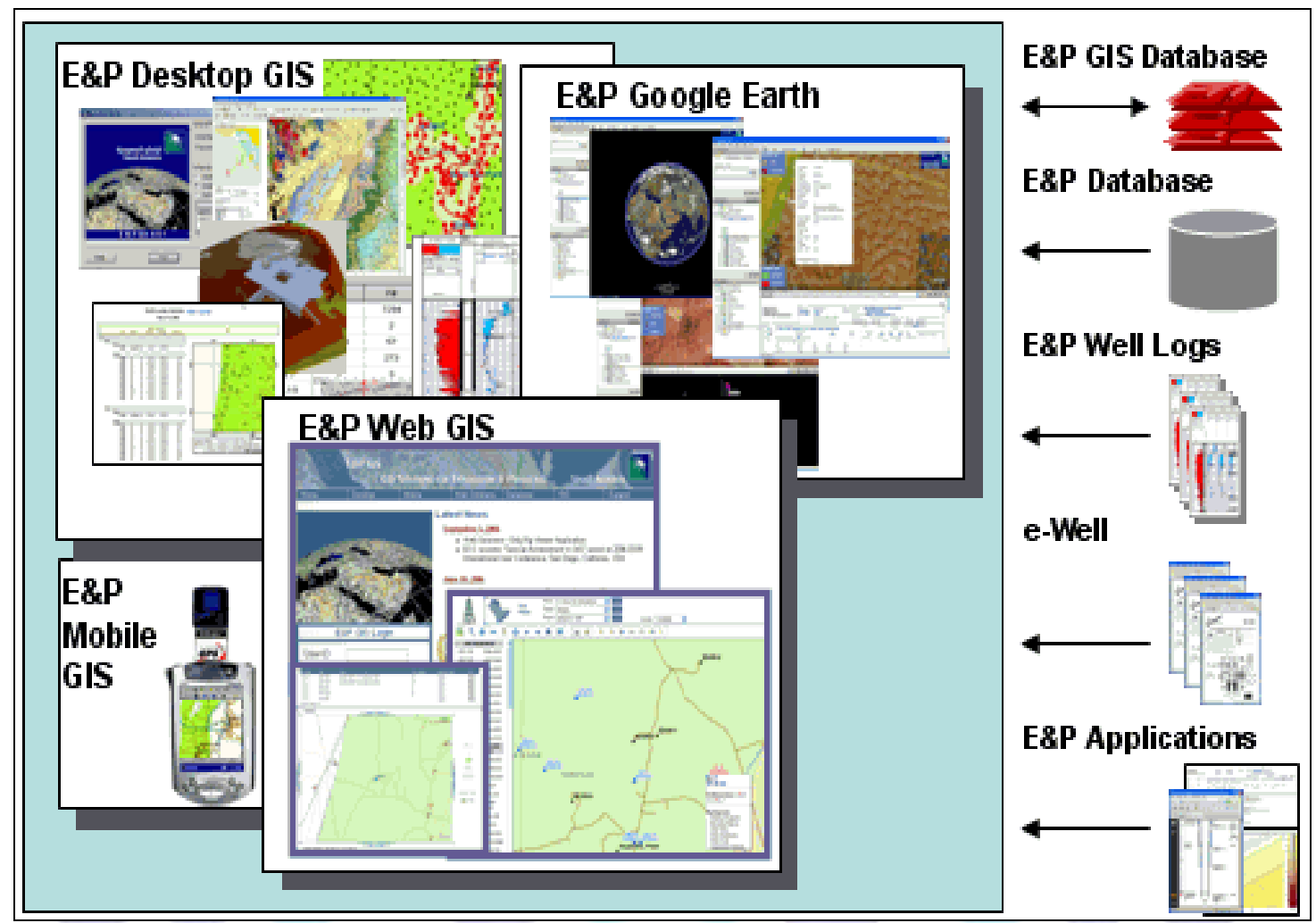

Figure 6: show a Saudi Aramco Company E\&P GIS Systems from [5]

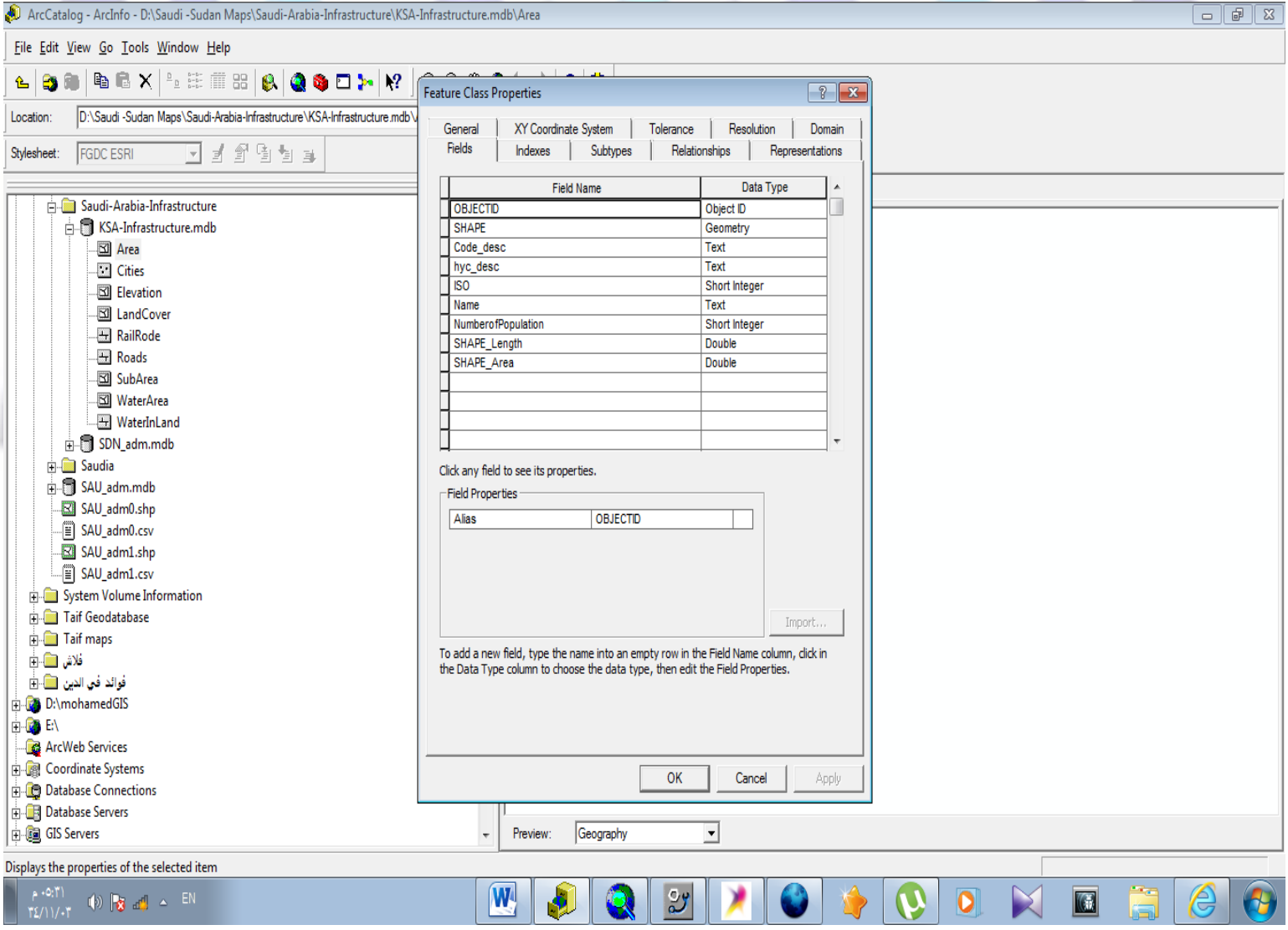

Figure 7: The Geodatabse layers and their attributes in ArcCatelog Platform. 
Three main GIS coverage's were digitized and captured using GIS software (ArcGIS 9.3) and the geodatatbase was designed and crated using ArcCatelog 9.3. These are Area, SubArea, Cities consisting the land base while the water in land, water area, roads, railroads, elevation and Land cover showing the features dataset of the infrastructure of KSA land; that shows as Layers. Each one of these digital coverage has also several attributes such as road types, land uses, number of population, area name, and characteristics and epidemiology data for diabetic. All of the collected data have been digitized and given a uniform reference in ArcGIS. Figure 4 show The geodatabse layers and their attributes in ArcCatelog Platform version 9.3.

\section{Research Methodology}

\section{A. GIS HAS SEVERAL TECHNIQUES}

GIS has several techniques and functions that can be used for Infrastructure service planning. Each one of these functions can be applied on different infrastructure related issues. For example, the issue of water in land and water area accessibility can be modeled in GIS using simple functions such as buffer function or using spatial data analytical functions such as spatial analysis technique. This study has selected three major infrastructure planning issues and uses GIS for analyzing these issues. The first issue is related to defining the water in land and water area location. The second issue in the roads and rail roads while the third is the production and exploration of petrol. GIS has different tools that can be used for defining any location on the map. Google earth was used to show the elevations of Saudi Arabia Areas using argGIS and arcCatelog presented to study and capture and define infrastructure location at Saudi Arabia [33-39].

\section{B. THE XML OF SAUDI ARABIA GEODATABASE FEATURES DATA SET} $<\ldots>$

$<$ Area $>$ Area $<$ Area $>$

$<$ Subarea $>$ Subarea $<$ Subarea $>$

$<$ Cities $>$ Cities $</$ Cities $>$

$<$ WaterlnLand $>$ Waterlnland $<$ WaterInLand $>$

$<$ Water-Area $>$ WaterArea $<$ Water-Area $>$

$<$ Roads $>$ Roads </Roads $>$

$<$ Railroads> Railroads </Railroads>

$<$ elevation > Elevation </elevation>

$<$ Landcover> LandCover </Landcover>

<Poulations> USAddress </Poulations>

$<$ SSaudia Arabia Geodatabase Features $>$

$</ \ldots>$

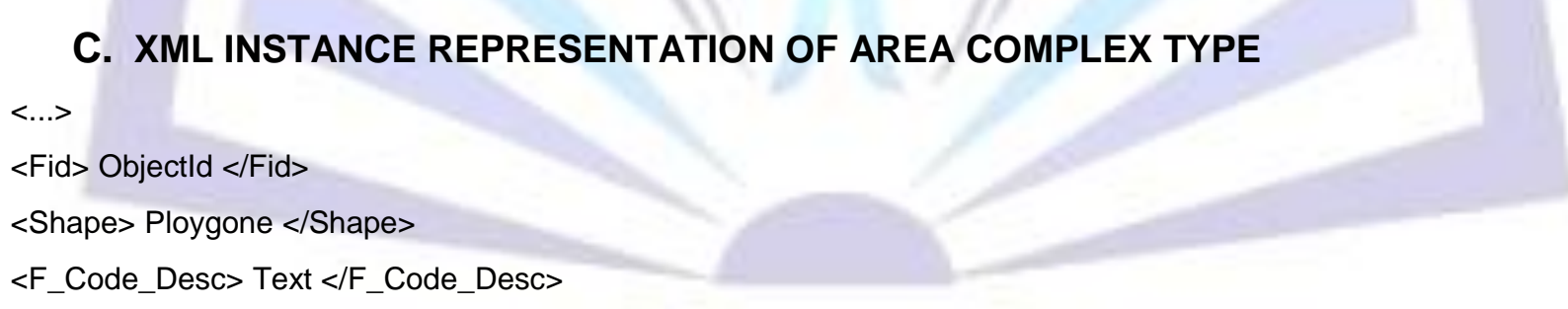

$<$ Hyc-Desc $>$ Text $</$ Hyc-Desc $>$

$<$ lso $>$ Integer $<$ /lso $>$

$<$ Name $>$ Text $<$ /Name $>$ ]

$<$ Number of population $>$ Integer $<$ /Number of population $>$

$</ \ldots>$ 


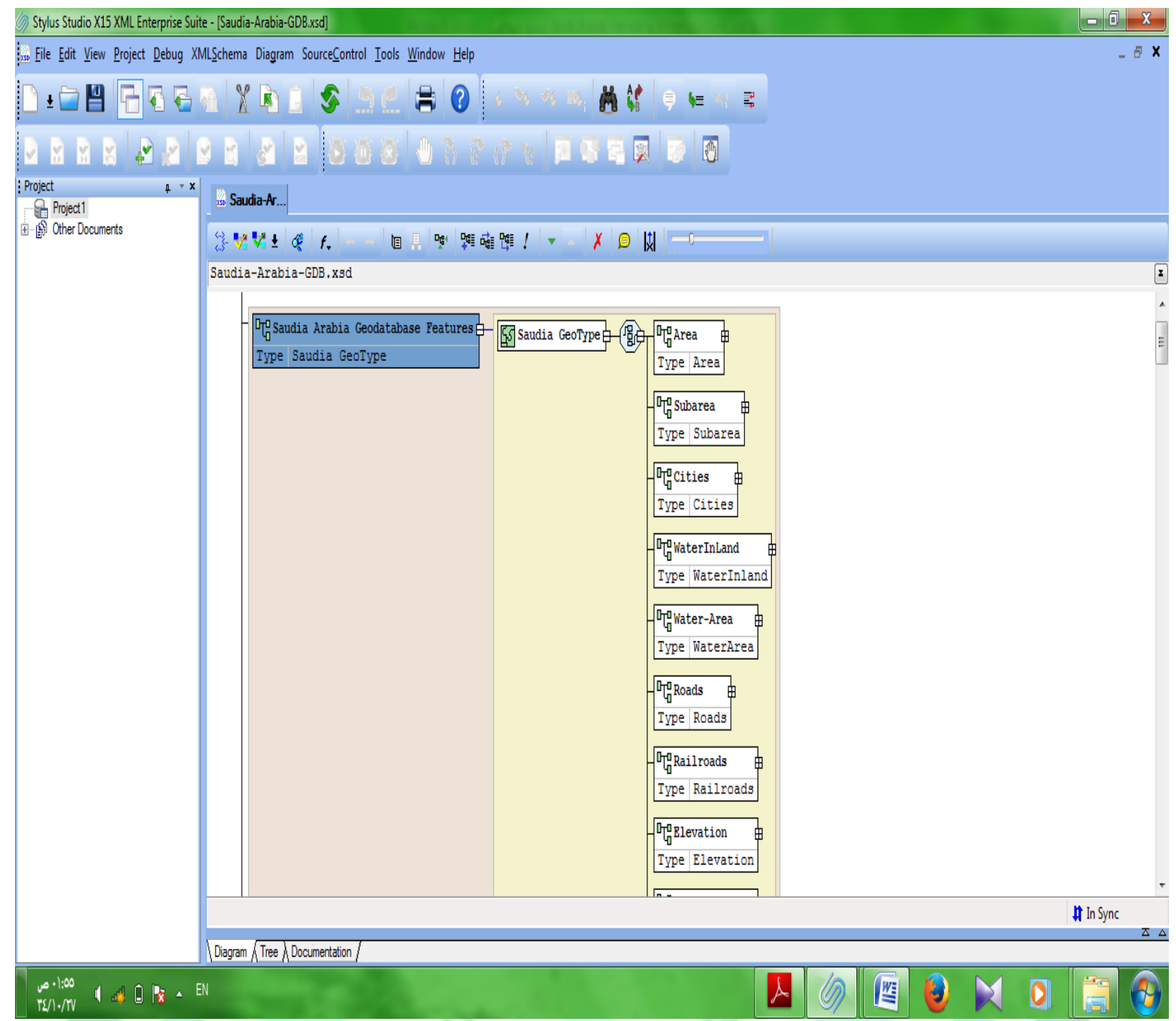

Figure 8: Shows the style studio XML software platform where the Infrastructure.

ArcGIS software is used by the presented study to define the land base layers(area, subarea, Cities) and the infrastructure that consists of (Water in land, water area, roads, railroads, elevation and land cover). These data are collected on subarea districts level. Therefore, GIS coverage is digitized at the Arcmap application, which is one of the main ArcGIS 9.3 applications, using polygon-draw inities ) $\mathrm{g}$ tools that are located at the editor menu. After creating the required Area, and subarea district polygons in ArcGIS 9.3 software, the following step was taken to enter the collected attributes about the land base and the infrastructure attributes. These include subareas and Cities names population on subarea and. All of these data are linked to the demand coverage and used for the second issue of this application which is related to the classifications of different infrastructures attributes Figure 7 Shows the style studio XML softwareplatform where the Infrastructure as XML diagram and The XML of Saudi Arabia Geodatabase Features data set. 


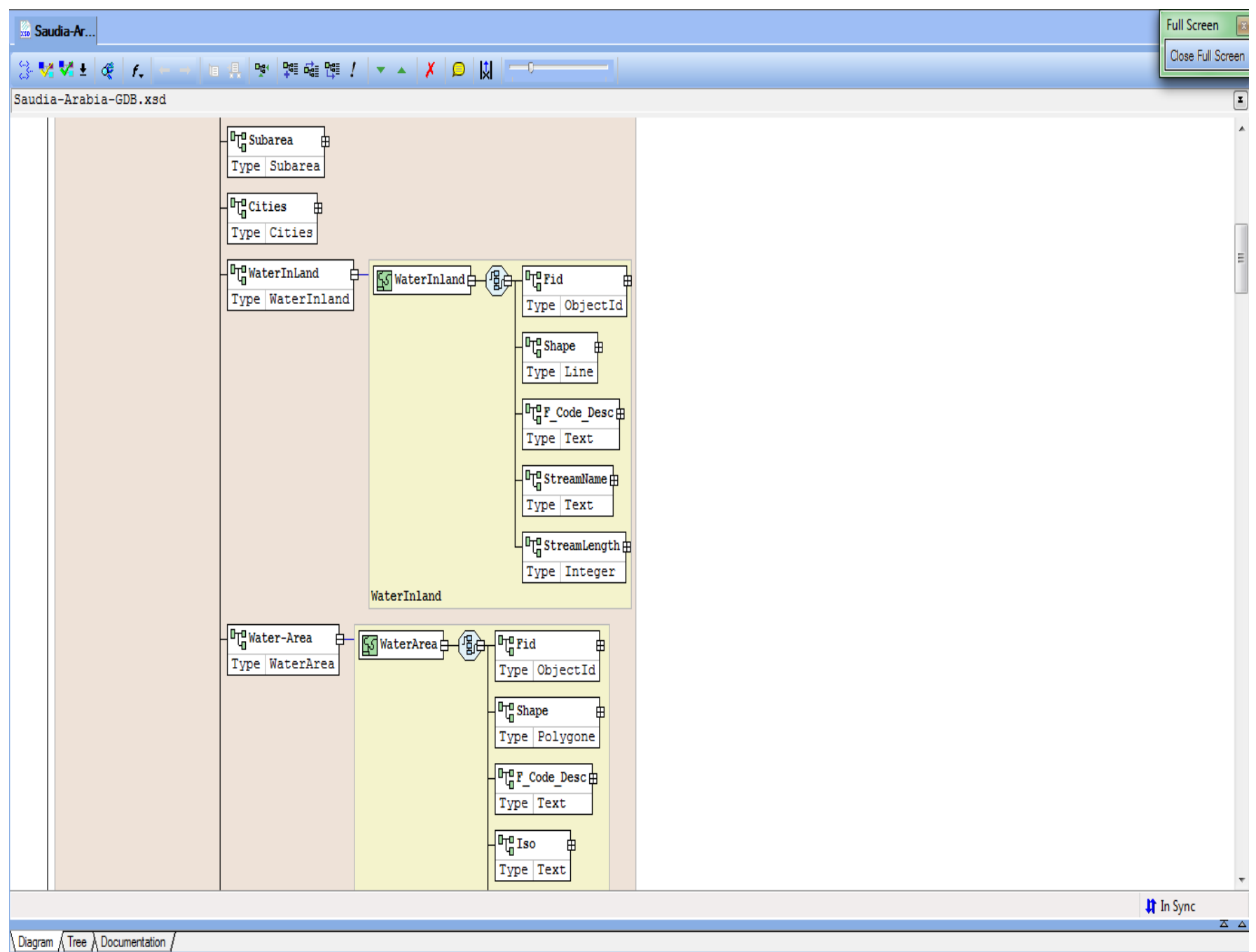

Figure 9: Shows water in land and water area XML diagram

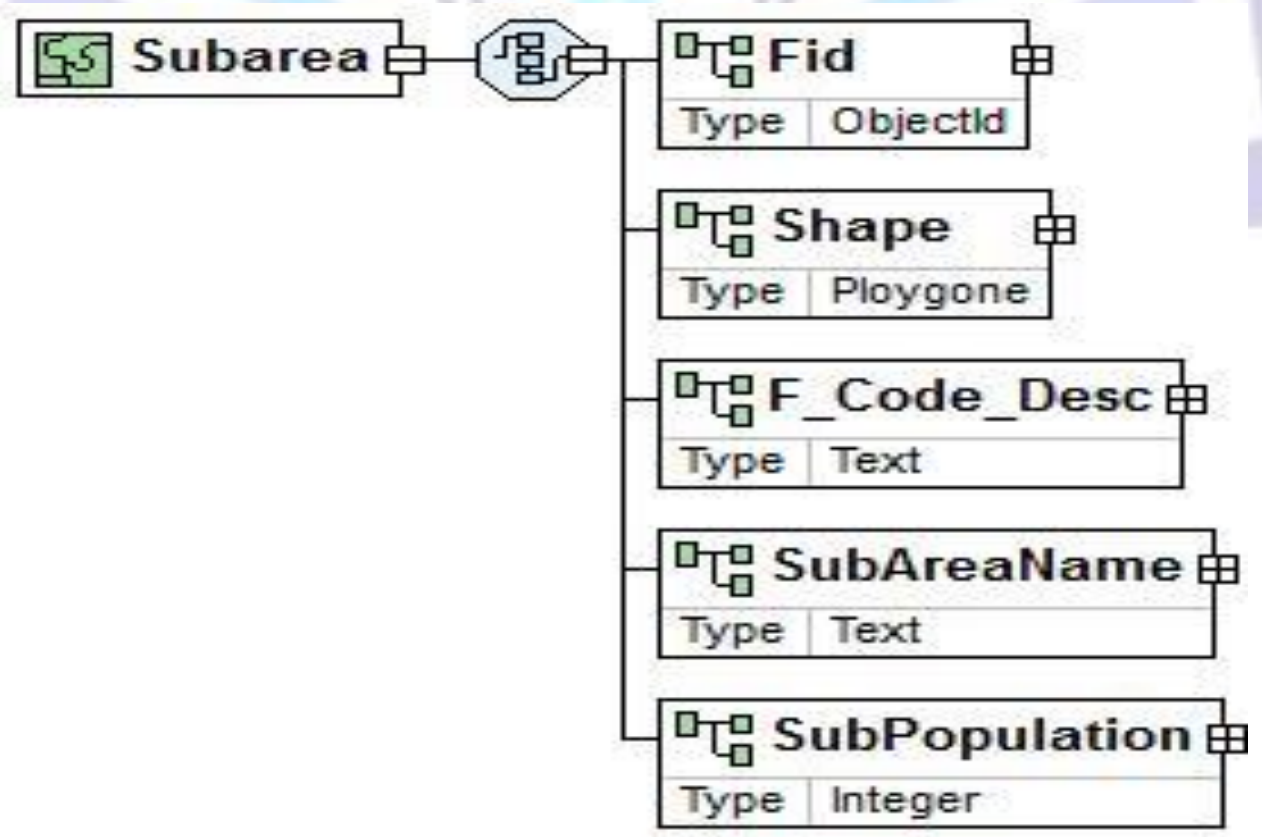

Figure 10: shows the Subarea Feature Class Diagram 


\section{System flow charting}

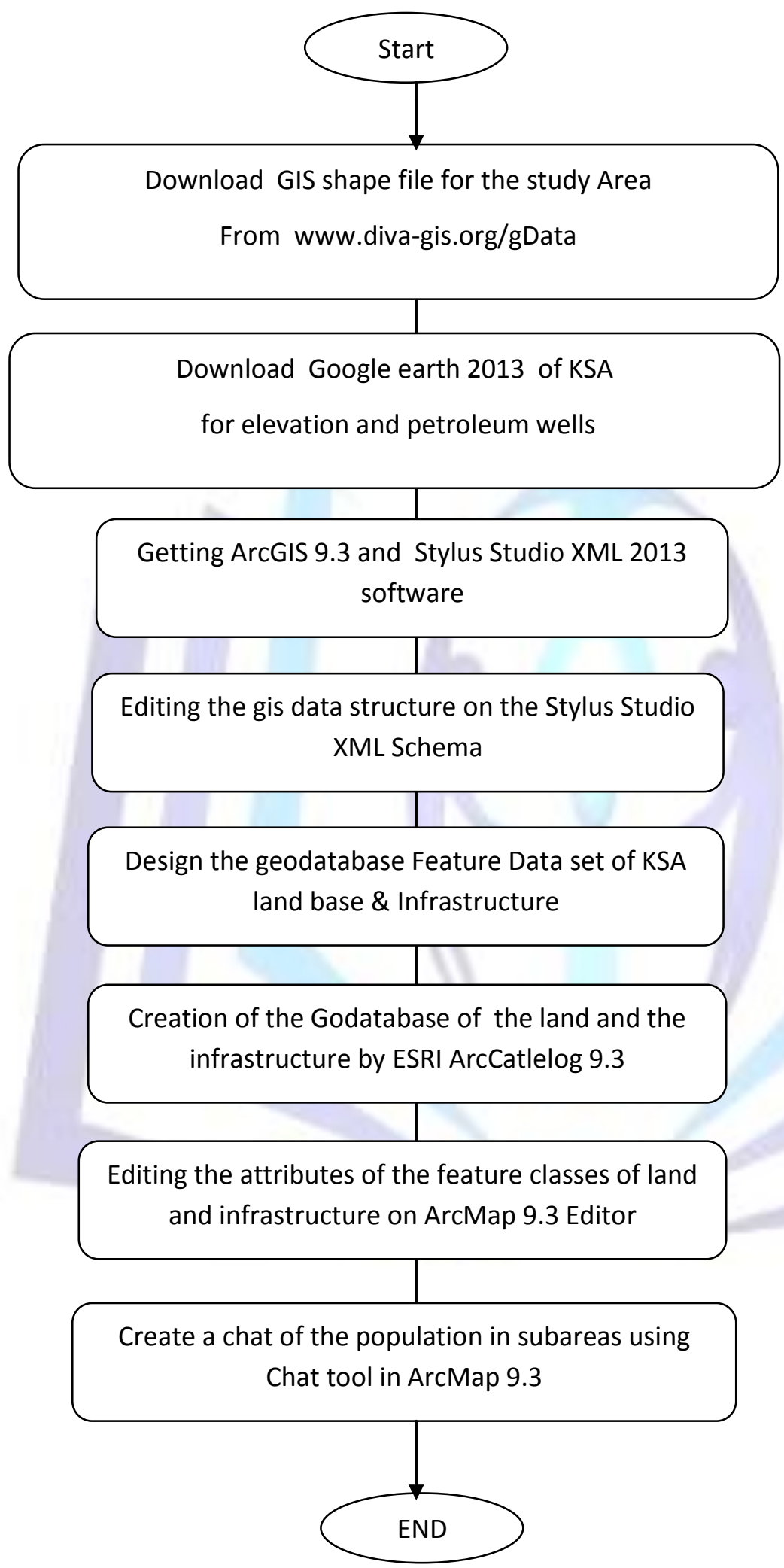

Figure 11:Shows the flow chart of the proposed system. 


\section{IV.THE IMPLEMENTATION OF THE SYSTEM}

A-Water in land GIS features class Leyer

XML Instance Representation of water inland complex type $<\ldots .>$

$<$ Fid $>$ Objectld $<$ /Fid $>$ [1]

$<$ Shape $>$ Line $</$ Shape $>$ [1]

$<$ F_Code_Desc $>$ Text $</ F \_C o d e \_D e s c>[1]$

$<$ StreamName $>$ Text $</$ StreamName $>$ [1]

$<$ StreamLength $>$ Integer $</$ StreamLength $>$ [1]

$</ \ldots>$

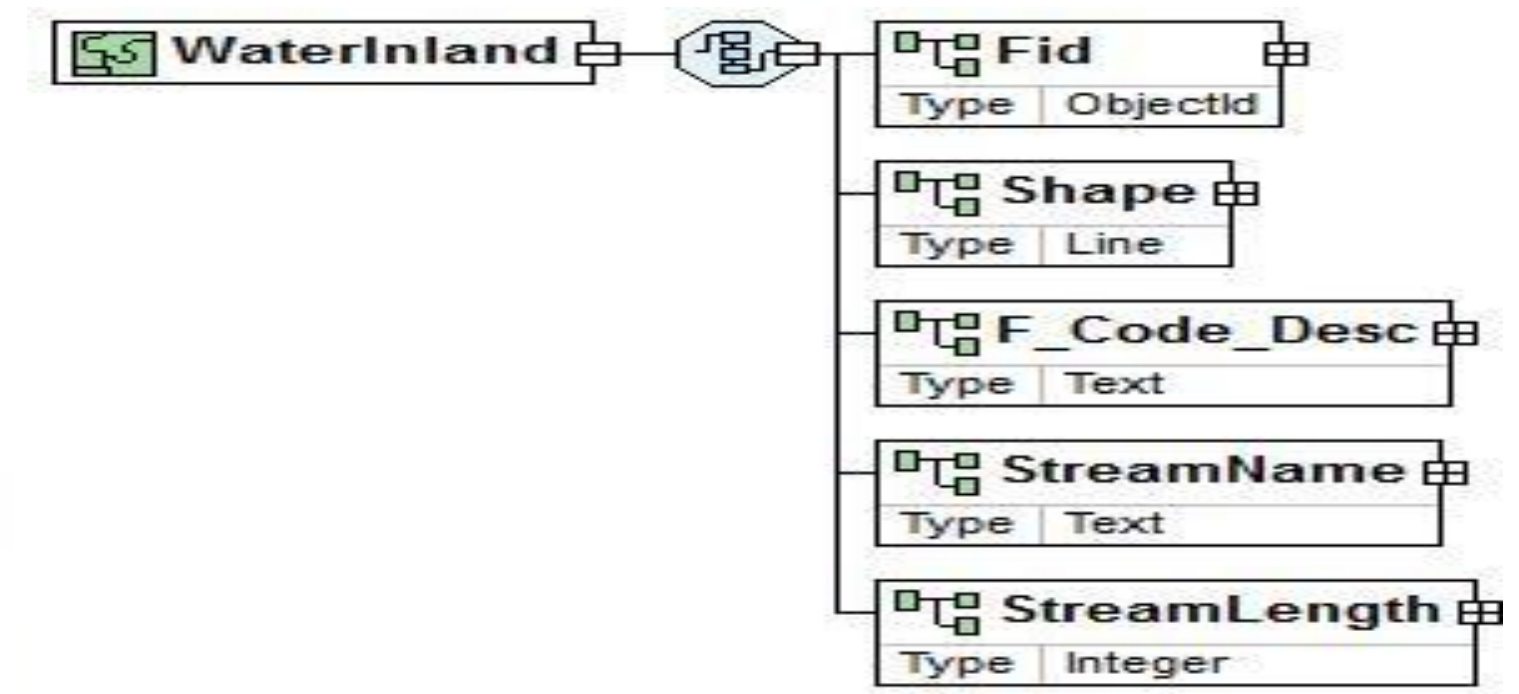

Figure 12 : Shows the diagram of Water inland attributes

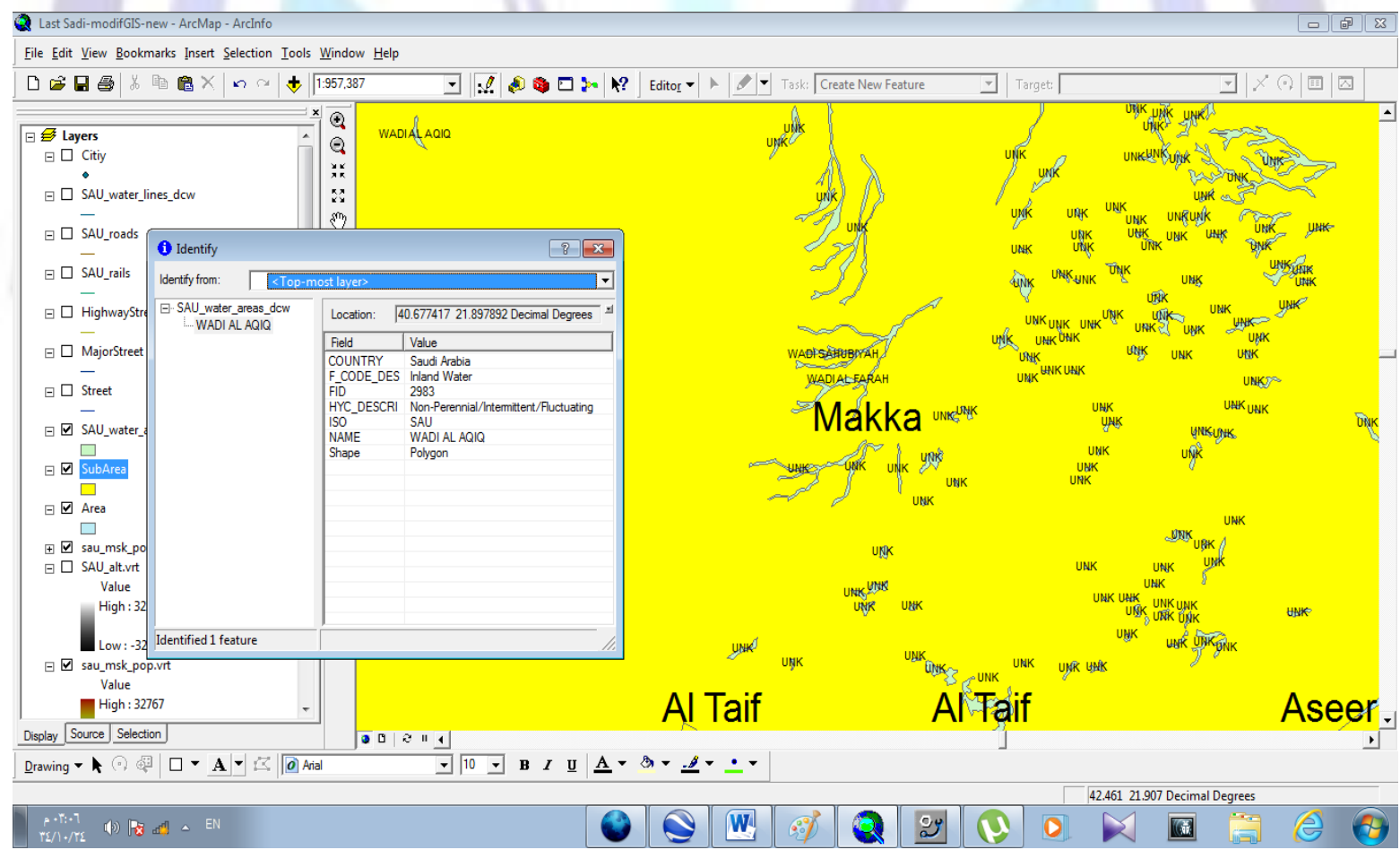

Figure 13: shows Wadi alaqiq on Makka Area. 
B-WATER AREAS GIS FEATURE CLASS LAYER

XML Instance Representation of water area complex type

$1-<\ldots>$

2- $<$ Fid $>$ Objectld $</$ Fid $>$ [1]

3- $<$ Shape $>\underline{\text { Line }}</$ Shape $>$ [1]

4- $<$ F_Code_Desc $>$ Text $</ F$ Code_Desc $>$ [1]

5- $<$ AreaName $>$ Text $<$ StreamName $>$ [1]

$6-</ \ldots>$

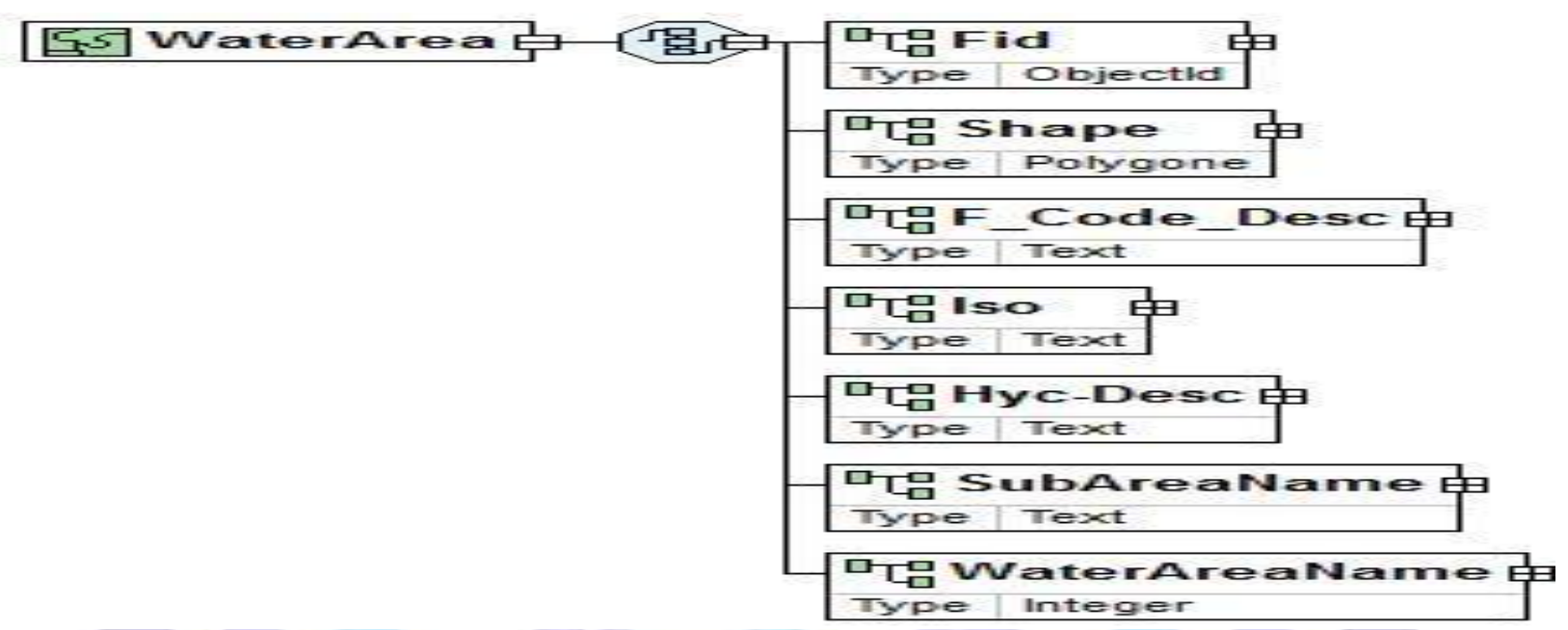

Figure 14: Shows the diagram of Water area feature Class attributes.

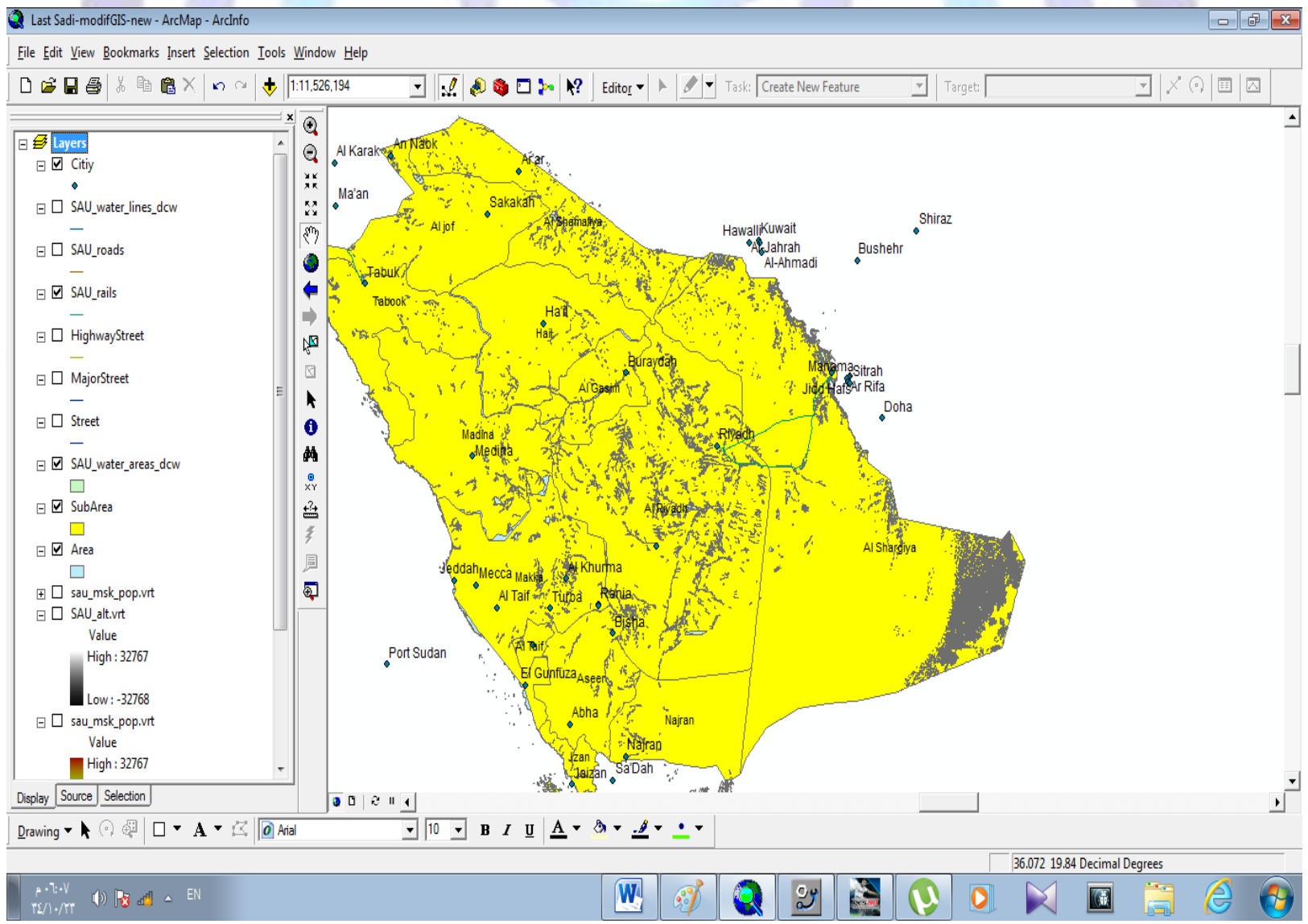


Figure 15: shows the Water Ares map in Saudi Arabia

\section{C-ROAD GIS FEATURE CLASS LAYER}

\section{XML Instance Representation of Roads Complex type}

$<\ldots>$

$<$ Fid $>$ Objectld $<$ Fid $>$ [1]

$<$ Shape $>$ Line $</$ Shape $>$ [1]

$<$ Med_Desc $>$ Text $<$ Med_Desc $>$ [1]

$<$ Rtt-Desc $>$ Text $</$ Rtt-Desc $>$ [1]

$<$ F_Code-Desc $>\underline{\text { Text }}</$ F_Code-Desc $>$ [1]

$<$ lso $>$ Text $</$ lso $>$ [1]

$<$ RoadName $>$ Integer $</$ RoadName $>$ [1]

$<$ SubAreaName $>\underline{\text { Integer }}</$ SubAreaName $>$ [1]

$</ \ldots>$

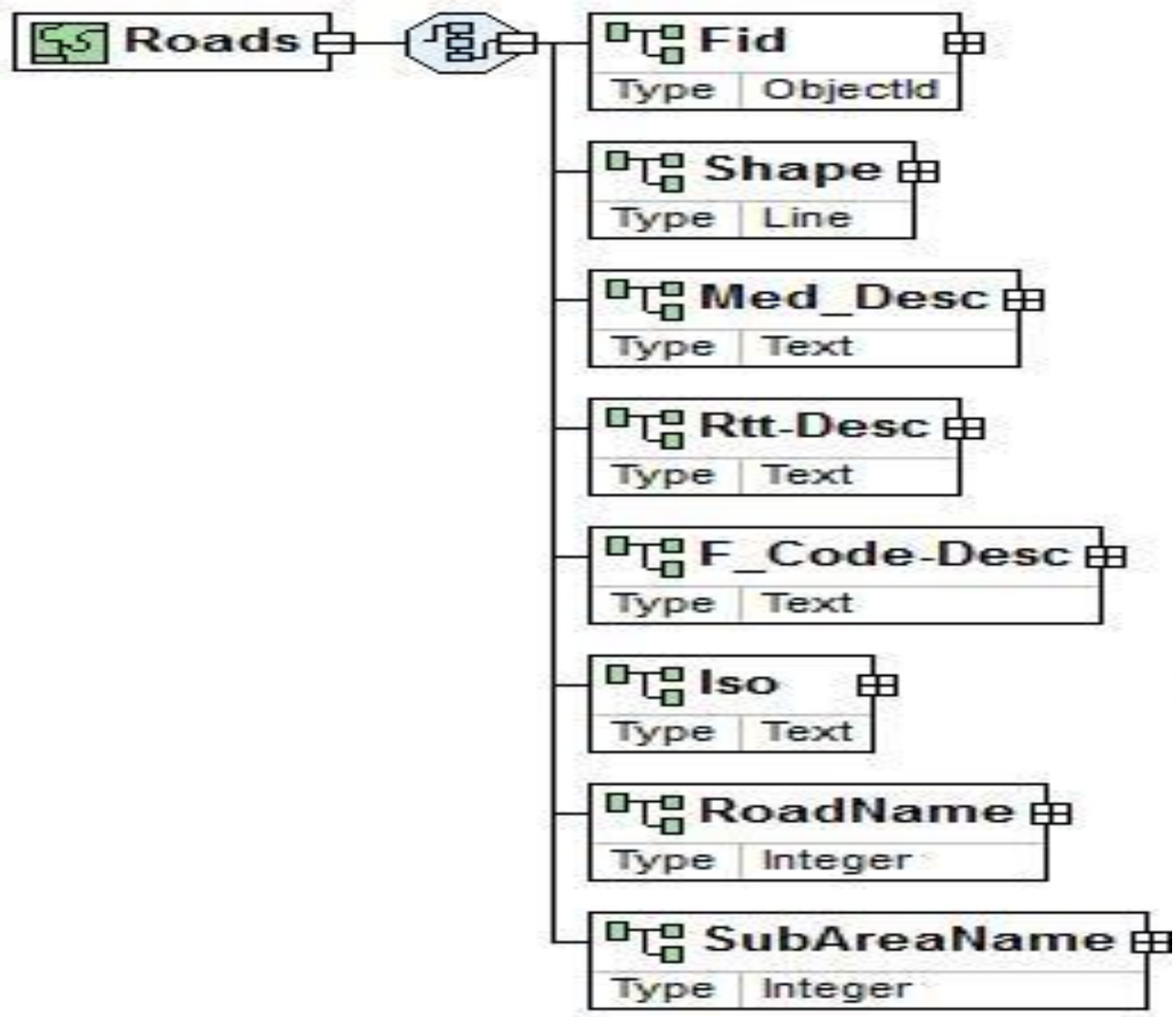

Figure 16: shows the Roads Feature class attributes 


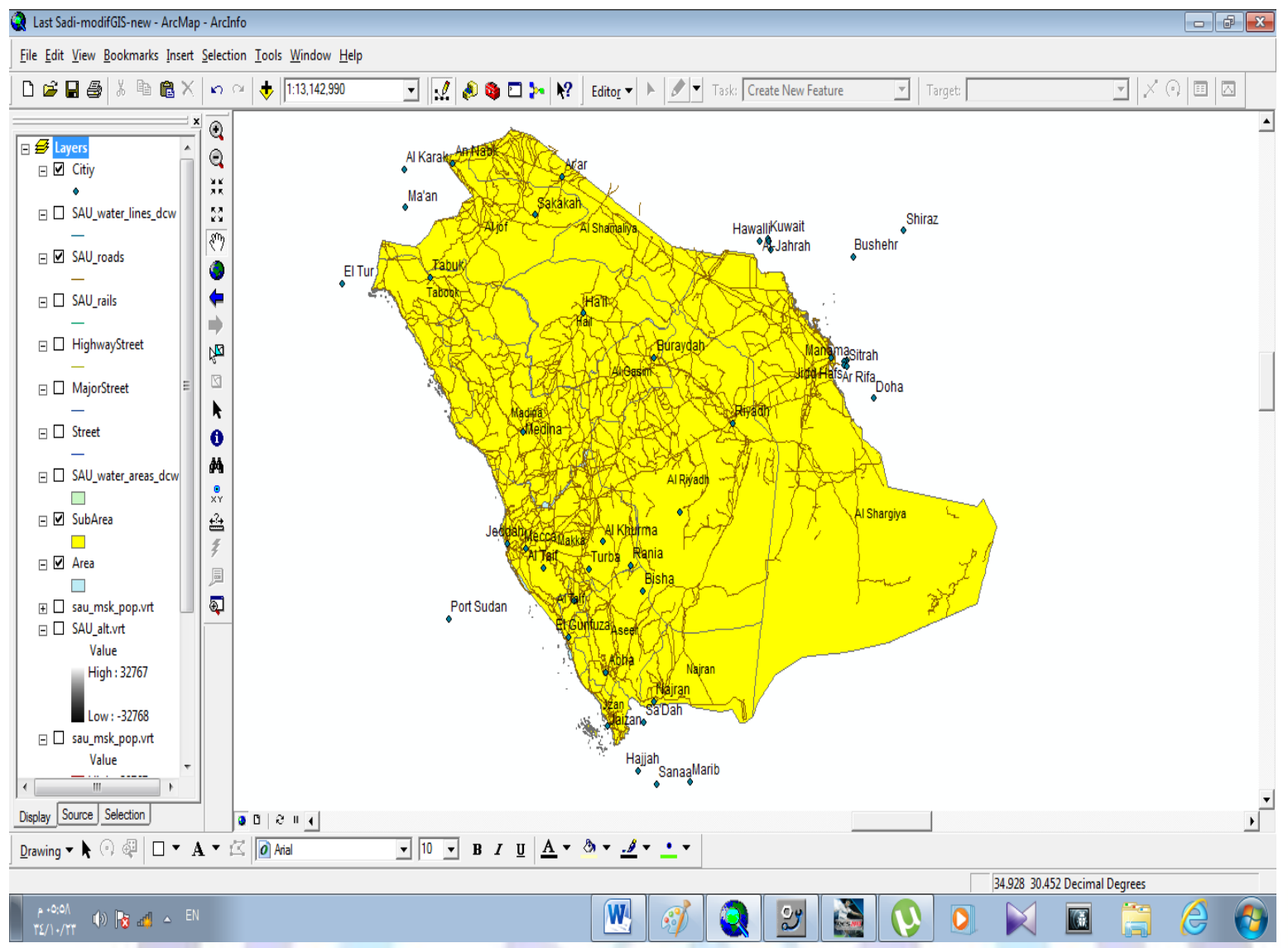

Figure 17: shows the Natural Roads On different Saudi Arabia Areas

\section{D-RAIL ROADS GIS FEATURE CLASS LAYER}

- XML of Rail Roads Complex type

$<\ldots>$

$<$ Fid $>$ Objectld $<$ /Fid $>$ [1]

$<$ Shape $>$ Line $</$ Shape $>$ [1]

$<$ Med_Desc $>$ Text $</$ Med_Desc $>$ [1]

$<$ Rtt-Desc $>$ Text $</$ Rtt-Desc $>$ [1]

$<$ F_Code-Desc $>\underline{\text { Text }}</$ F_Code-Desc $>$ [1]

$<$ Iso $>\underline{\text { Text }}</$ Iso $>$ [1]

$<$ RailName $>$ Integer $</$ RailName $>$ [1]

$<$ SubAreaName $>$ Integer $</$ SubAreaName $>$ [1]

$</ \ldots>$ 


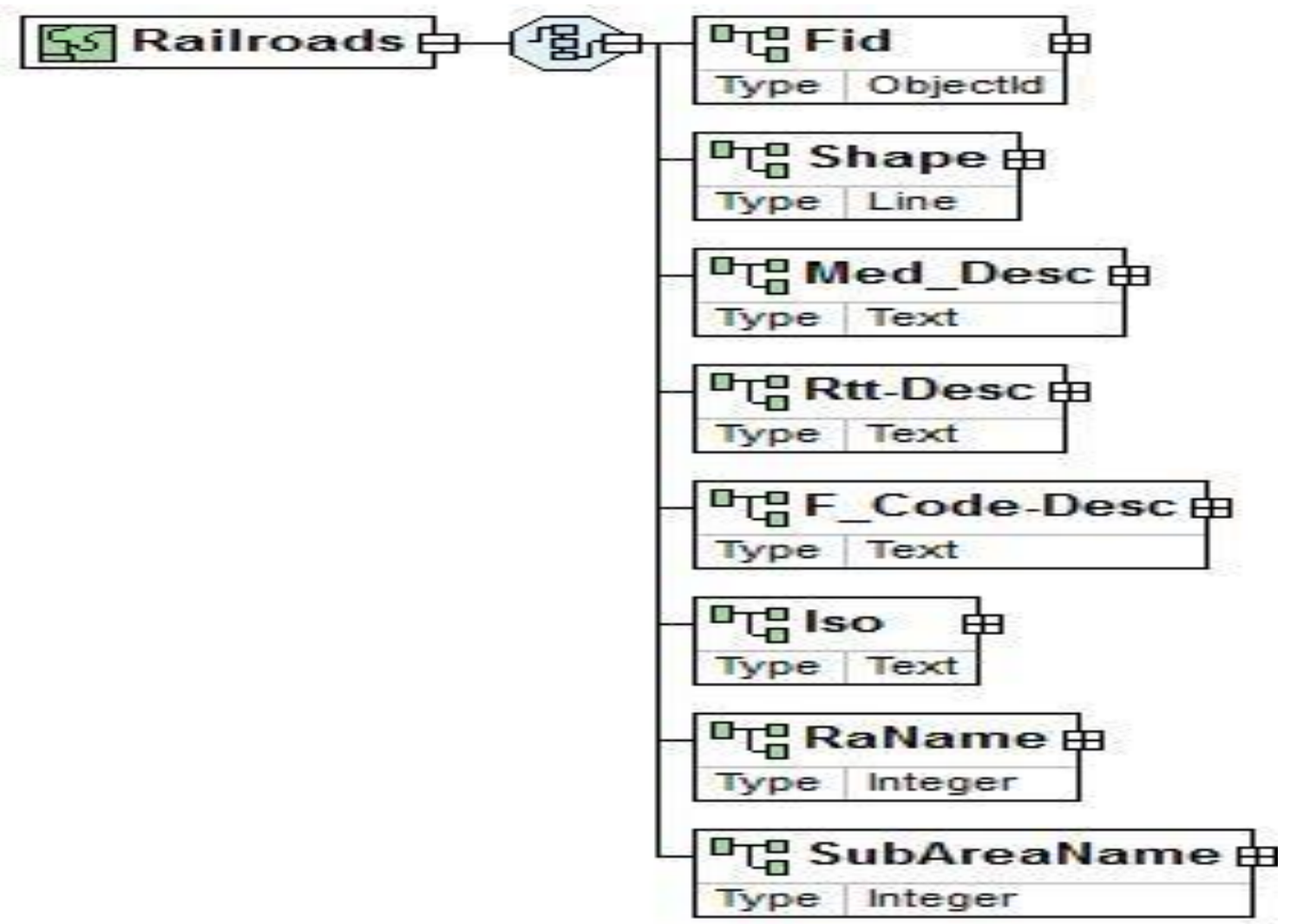

Figure 18 : shows the Rail road Feature Diagram

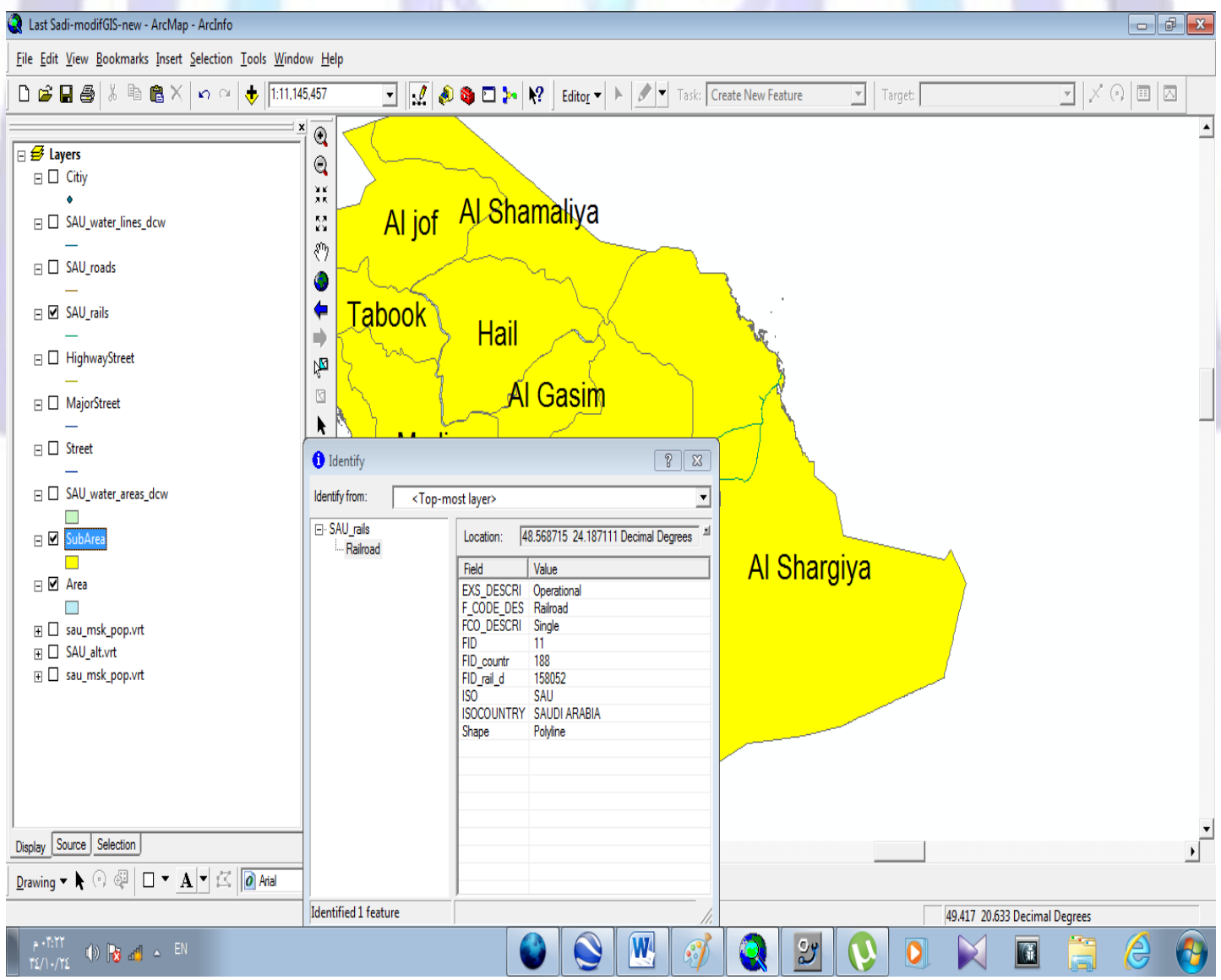

Figure 19: shows the railroad on eastern area of Saudi Arabia 


\section{E. USING GOOGLE EARTH TO STUDY TH ELEVATION OF SAUDI ARABIA LAND BASE}

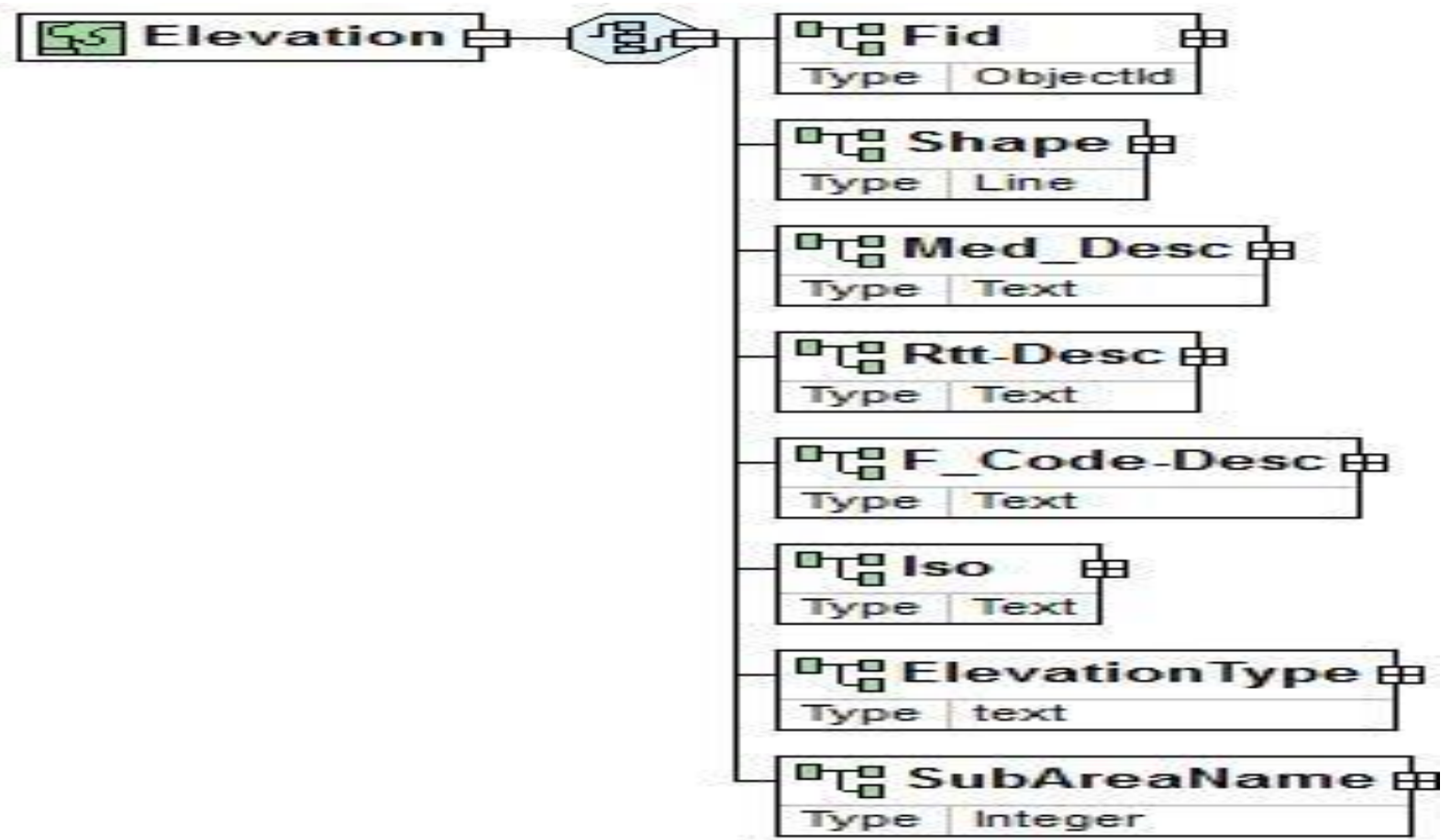

Figure 20: shows the elevation feature class

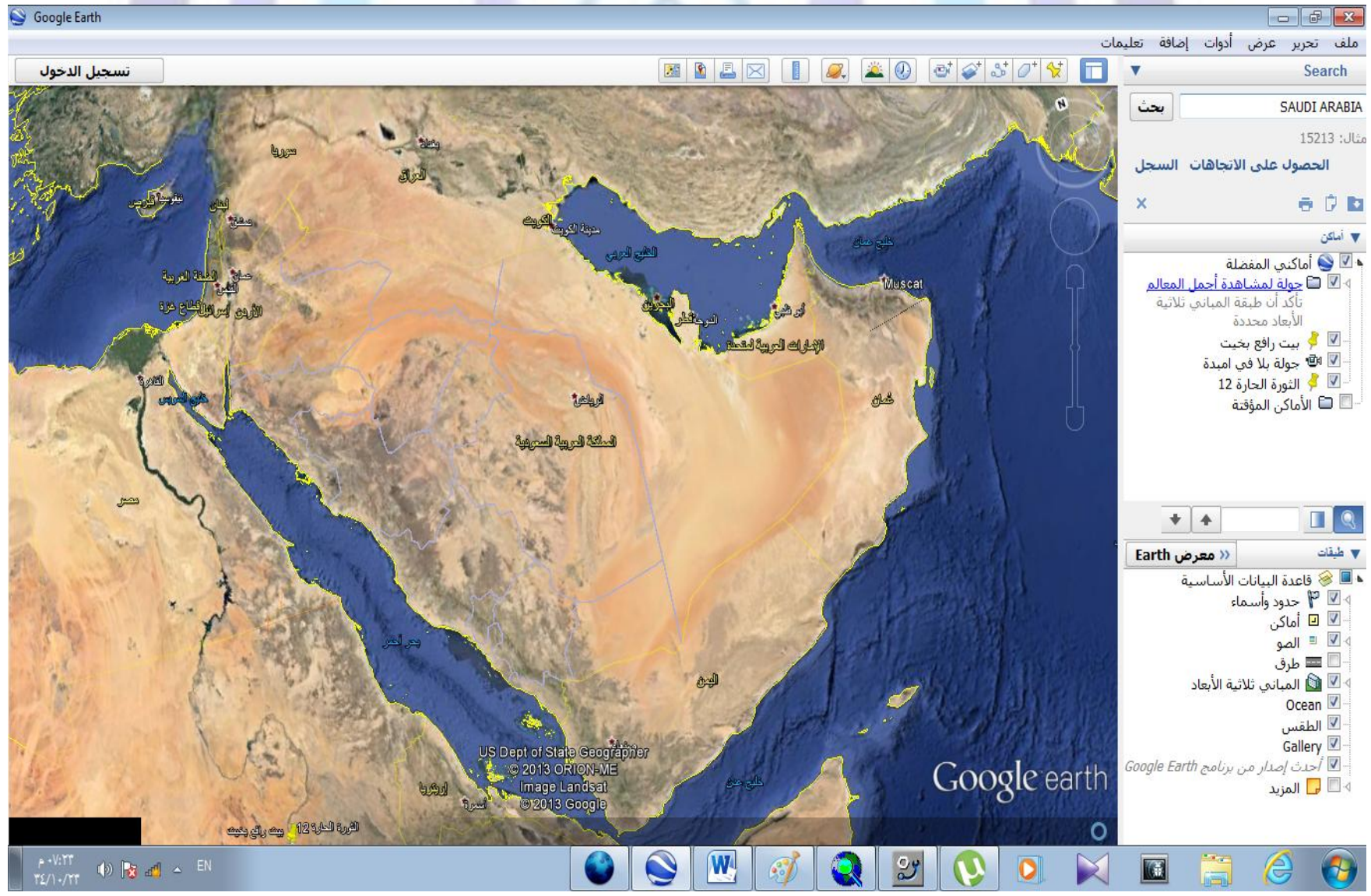

Figure 21: shows the elevations of KSA on Google earth 2013. 


\section{STUDYING SAUDI ARAMCO E\&P GIS SYSTEMS USING ARCGIS SOFTWARE}

\section{A. SAUDI ARAMCO'S E\&P PORTFOLIO}

Saudi Aramco's E\&P portfolio contains a multitude of spatial data on potential hydrocarbon accumulations. It also contains data on reserves, well locations, seismic surveys, satellite and aerial imagery, surface topography and existing infrastructure information. Major challenges in managing such a portfolio are that of ensuring data is kept up-to-date in a secure environment, a consistent evaluation with a clear audit trail is applied throughout and the data is available for integration with E\&P business risk planning engines [4-9].

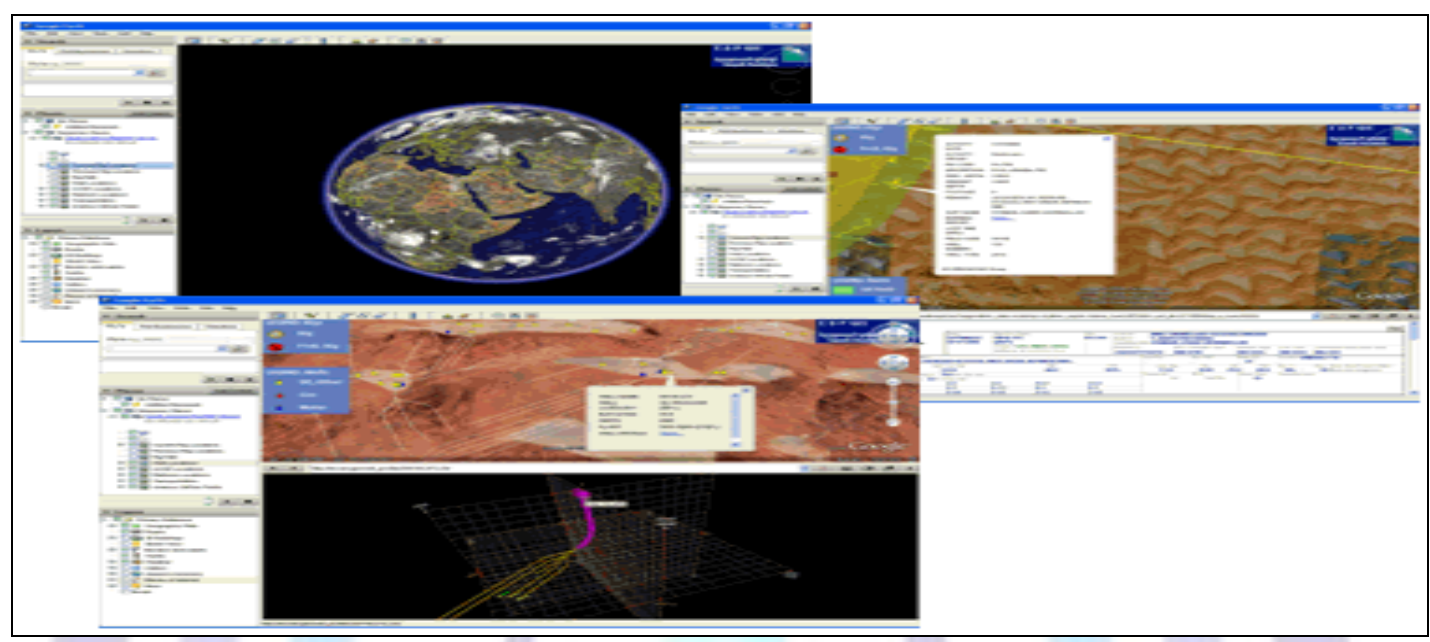

Figure 22: Shows E\&P Data Integration for Google Earth from [37]

\section{B. E\&P WELL DATABASE}

An interactive, custom, intelligent interface allows a user to define what information they would like retrieved from the E\&P Well database tables for wells selected on a map. Constraints can be imposed on the relational database to provide a basis for any analysis that is to be completed in a spatial context. The constraints are designed with a syntax very similar to the natural language of the relational database, i.e., SQL, and the interface has been developed to be intuitive as possible. The retrieved data can be exported to Excel or text file format for further analysis or displayed next to the well locations on the map. In addition, one or more columns for the retrieved data can be used to create custom maps that represent quantity, with proportional symbols, when well data - retrieved from the relational database - are used as measurement values, e.g., bubble maps.[5-19].

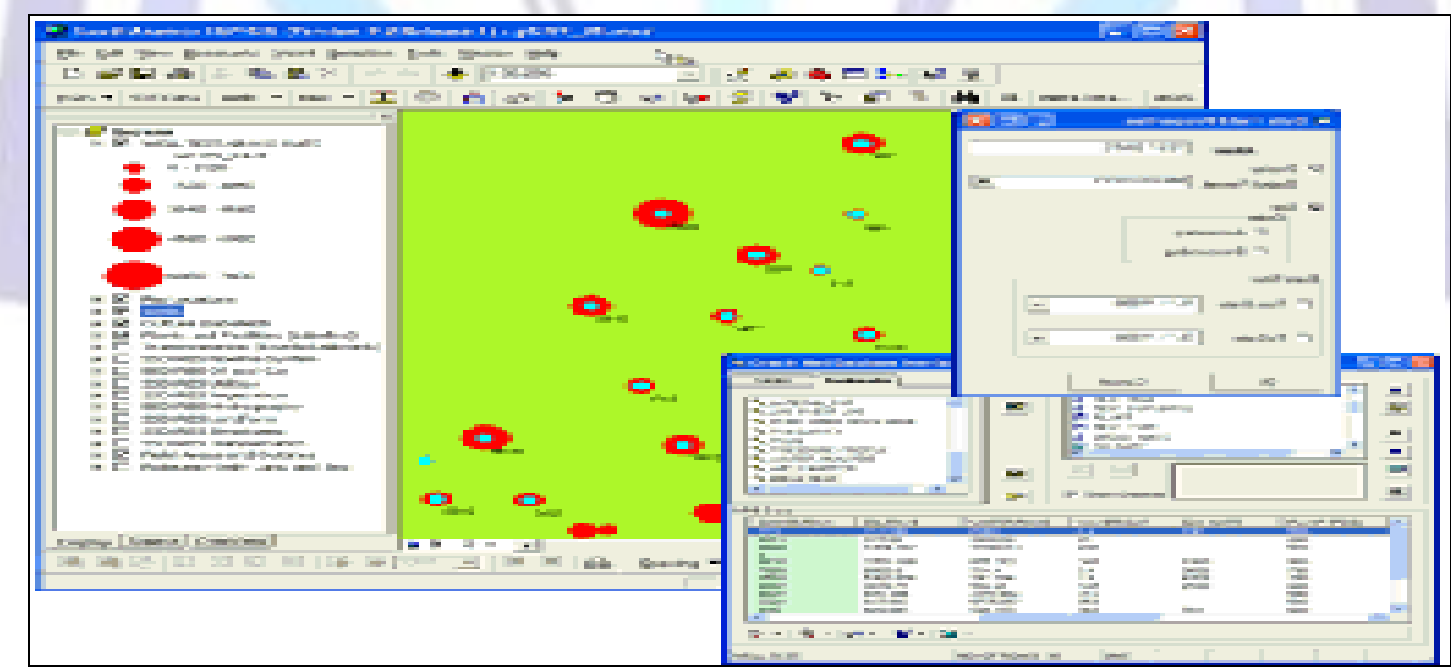

Figure 23: show the E\&p Well Locations In KSA from Aramco [37]

\section{GEOLOGIC MAPS \& SATELLITE IMAGERY}

The custom overview window of E\&P GIS can display and overlay for analysis geo-referenced geologic maps and satellite imagery residing in the E\&P GIS database. An index grid for the raster data shows the footprints available for display and analysis. The interactive hot-link tool allows a user to select a particular footprint and display it in a custom map viewer along with its metadata. The option to overlay the selected image on the main map window can then be used to merge the vector data for integrated analysis. Because we can only display and view satellite images using the three 
visible primary colors, any three of the available bands can be combined to highlight the particular features of interest[2028, 31].

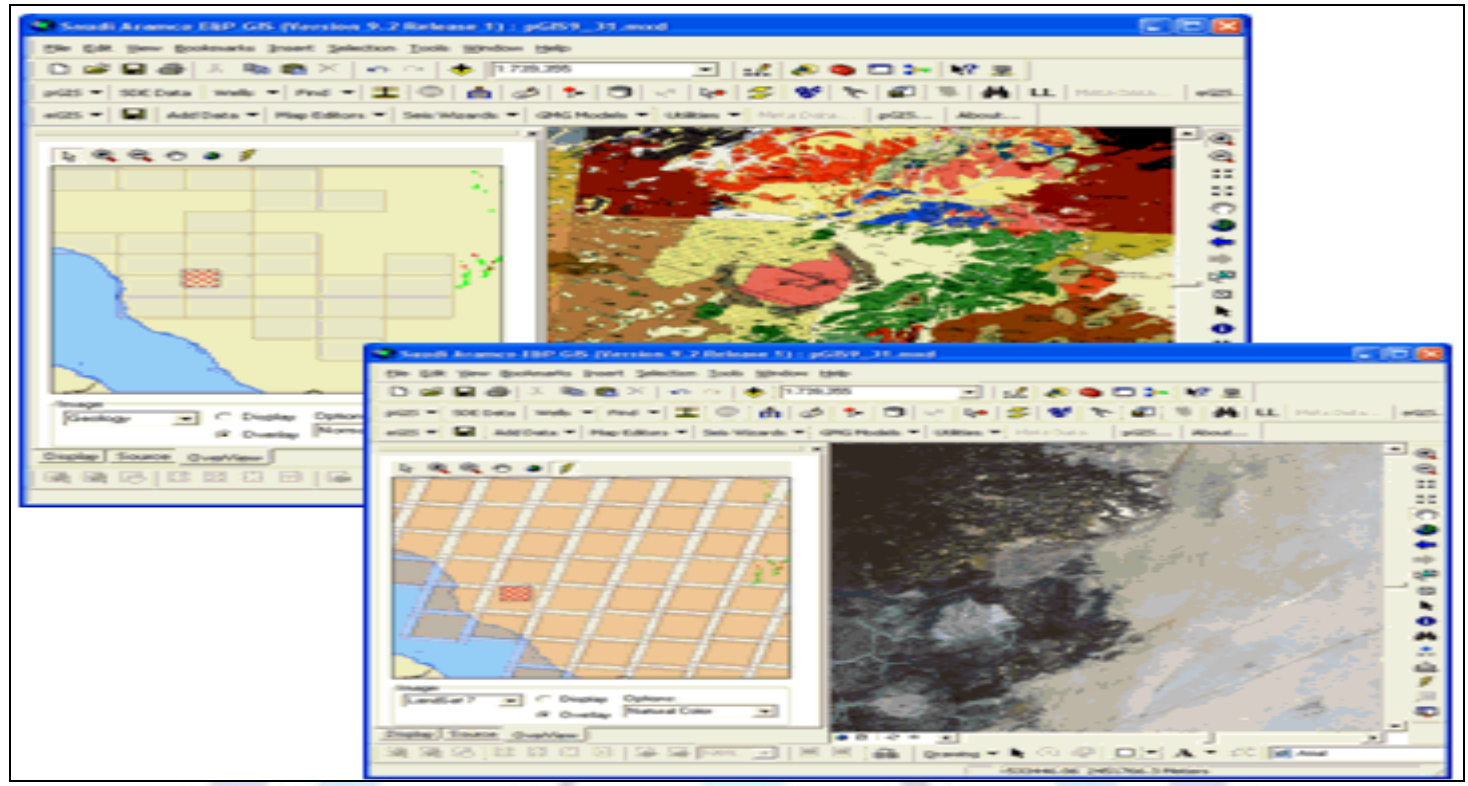

Figure 24: Shows Geologic Maps \& Satellite Imagery from Aramco from [37].

\section{Representation of Knowledge}

\section{A. KSA Land base Map}

The mechanism for changes of classes of KSA infrastructure data integration and data sharing. This mechanism allows an instance of a class to be generalized or specialized thus enabling information integration at different levels. Figure 25 shown how the KSA base map which composed of area, subarea and cities geodabase was created using ArcGIS 9.3 and ArcCatelog. Second it presented how the knowledge generated for water in land, water areas, and water damas and elevation geodatabase and map generation was done. Third the roads and rail roads geodatabase was build showing the way where petrol and water transformed. The different levels of information granularity and their relation to different levels of Geodatabse were discussed here. The navigation introduced here shortens the gap between generic and specialized Geodatabse, enabling the sharing of software components and information. The next section of this paper presents an assessment of alternatives for integrating Geodatabse [23-32].

\section{B. Information integration}

information integration was presented of the high-level integration of Geodatabses of the whole system base map and land activates of water, road and petroleum was discussed, followed by a discussion of low-level integration. A method for evaluating the potential for information integration was introduced. Forth charts showing the number of dams on water areas and water in land was done showing the most highest and most water capacities was measured and captured, the effects of the use of roles and of hierarchical structures in the representation of Geodatabses in the potential for information integration [29-37].

\section{C.-Guidelines for Implementation}

We are suggesting here specific tools for implementation. We know that these tools are not the only solutions but the evolution of ontology-driven information systems will lead to the use similar tools or to an evolution of these same tools. An ontology-driven information system deals with instances of classes.

\section{Creation of Infrastructure Geodatabase}

ArcCatelog version 9.2 was used to create and build the KS infrastructure personal Geodatabase of the KS land base and the feature datasets of Water in land and water areas, Roads, rail roads were designed. Figure 18 and 19 shown the creation of new personal Geodatabase on Access Database.

\section{VII . KSA Oil Company Explores the Advantages of Enterprise GIS}

A. GIS for Petroleum: Discovering new sources of petroleum ahead of the competition is one of the key ways to stay successful in the petroleum industry. A GIS can help you evaluate the potential for oil in promising locations. Exploration often requires analysis of satellite imagery, digital aerial photo mosaics, seismic surveys, surface geology studies, subsurface and cross section interpretations and images, well locations, and existing infrastructure information. A GIS can relate these data elements to the location in question in map form and allow you to overlay, view, and manipulate the data to analyze and understand its potential.GIS technology today 
allows you to manage the spatial components of these everyday petroleum "business objects," such as leases, wells, pipelines, environmental concerns, facilities, and retail outlets, in the corporate database and apply appropriate geographic analysis efficiently across the enterprise [33-38].

- Surveying and Exploration-ArcGIS Desktop (ArcEditor) is used extensively to plan seismic surveying missions, monitor the performance of contractor crews, and analyze geophysical data collected during the surveys.

- Engineering - A custom Mapping Wizard lets staff access a wealth of spatial data from the Oracle-ArcSDE repository and quickly create publication-quality maps, without needing to know anything about GIS technology or cartography. Customized ArcGIS applications are used to support well site planning, wellhead maintenance, and other engineering functions.

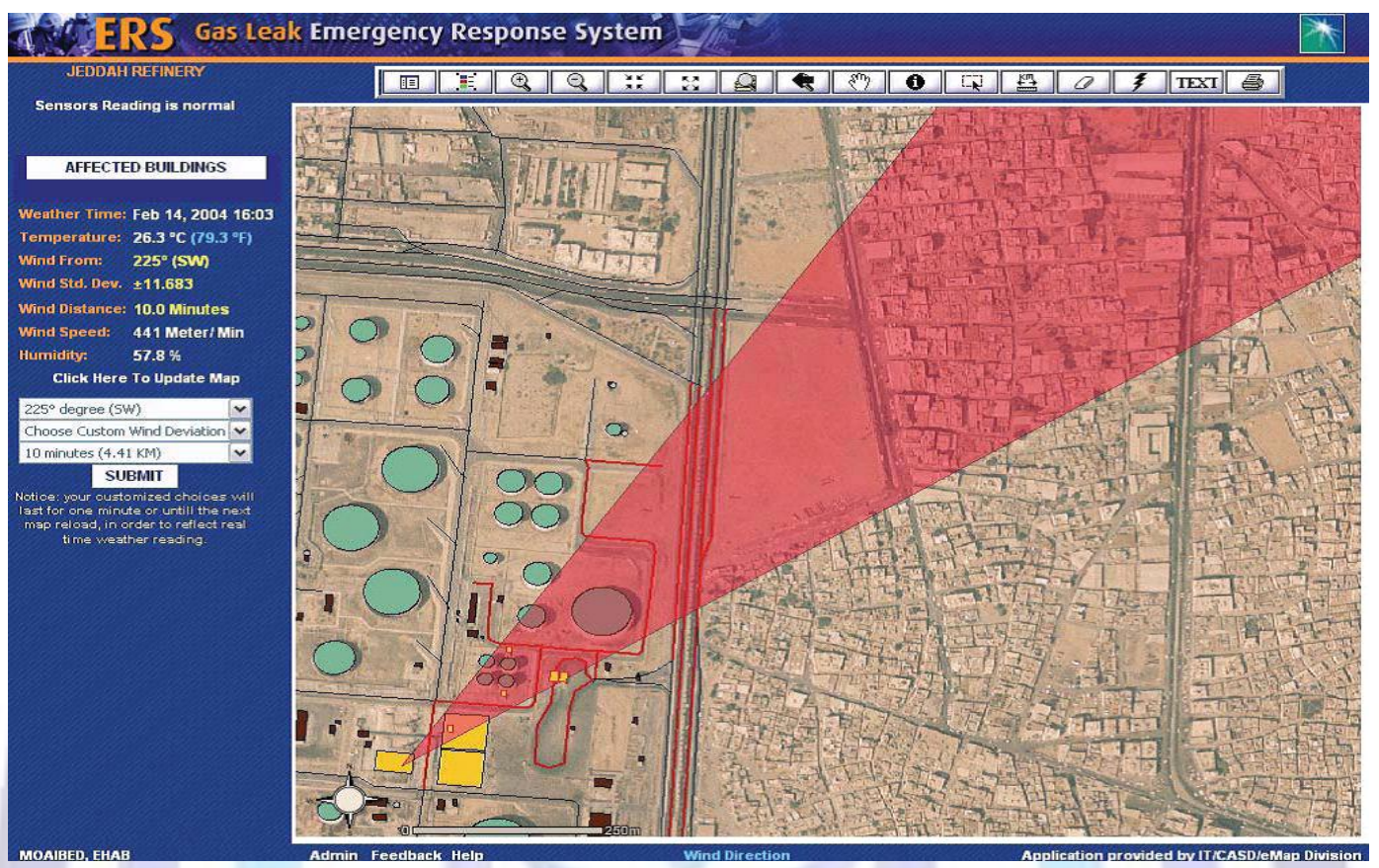

Figure 25 : show The emergency response system predicts the track of a gas leak.

- Logistics-The company's existing telecommunications infrastructure is being leveraged to dispatch and track the movement of company cars, heavy trucks, and ocean-going supertankers. Knowing the precise location of vehicles and vessels is essential for the timely delivery of goods and services. It also provides a lifeline for staff driving in remote desert locations.

- $\quad$ Planning-ArcEditor is used to digitize the location of all new facilities, and the resultant information is reviewed online by planners and engineers using dynamic ArcIMS maps. ArclMS has been integrated with a Web-based document management system to enhance decision making and reduce the project review time frame.

\section{B. Production, Export and Consumption of Peteroluim for Gulf Countries}

From study of petroleum production, export and consumption from [32] table and graphs was produced, on Middle East, the middle east (Persian /Arabian Gulf Region) is the world's oiliest petroleum porcine, with 64 percent of world's climates oil reserve and globe's highest potential rate capacity[33-38].

\begin{tabular}{|l|l|l|l|}
\hline Country & Year 1990 & Year 2000 & Year 2010 \\
\hline KSA & 3.5 & 3 & 2 \\
\hline Iran & 3.2 & 3.2 & 1.4 \\
\hline Iraq & 3.0 & 0.3 & 0.9 \\
\hline Kuwait & 0.6 & 0.8 & 0.79 \\
\hline A.E U & 0.56 & 0.9 & 0.8 \\
\hline
\end{tabular}

Table 3: Production of petroleum in billion beery $\mathrm{c} / \mathrm{m}$ 


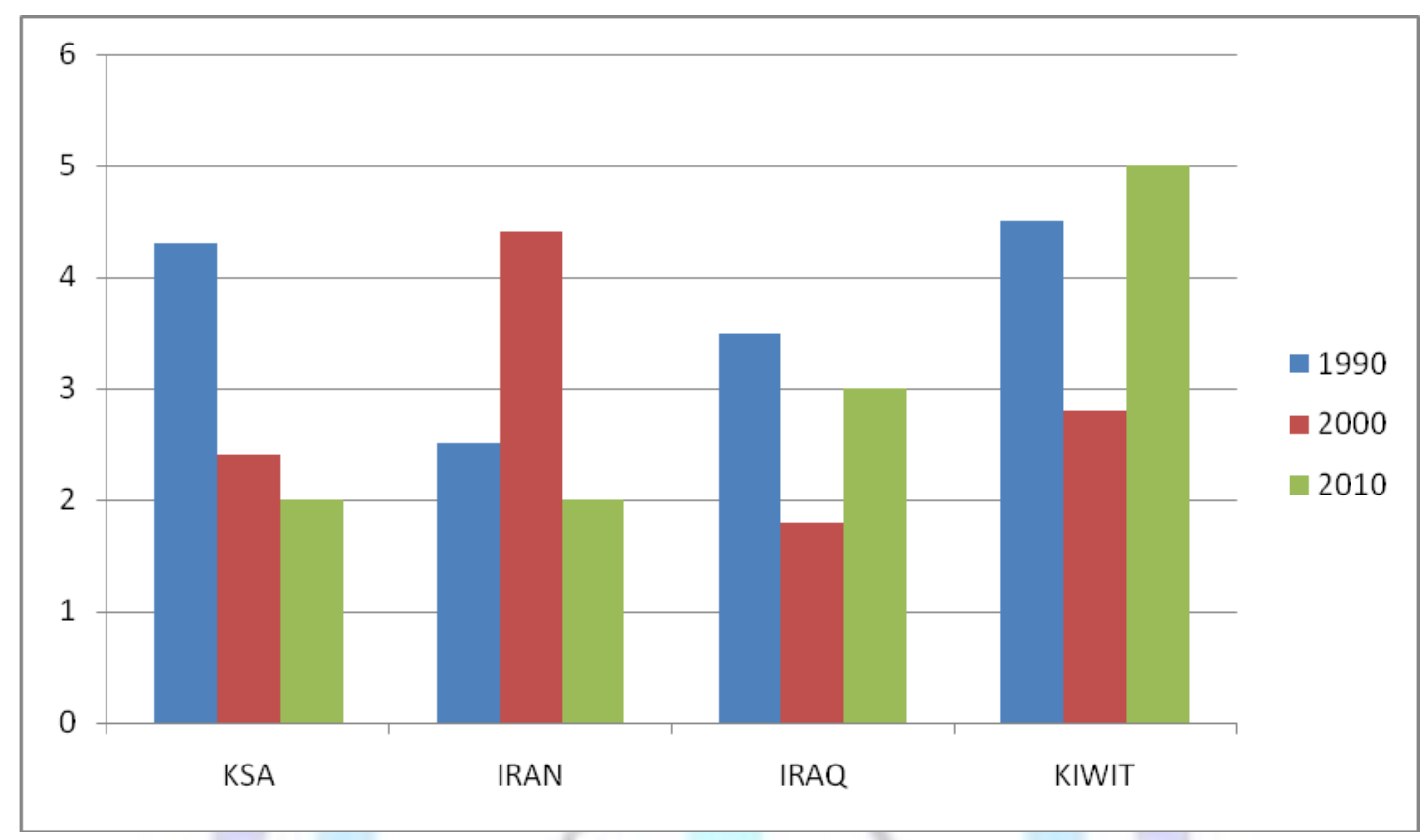

Chart 1 : Show chart of production of petroleum in year 1990,2000,2010.

\begin{tabular}{|l|l|l|l|}
\hline Country & Year 1990 & Year 2000 & Year 2010 \\
\hline KSA & 0.8 & 0.8 & \\
\hline Iran & 1.3 & 3.7 & 0.7 \\
\hline Iraq & 1.3 & 2.7 & 3.8 \\
\hline Kuwit & 1 & 2.2 & 2.8 \\
\hline .A.E U & 1.5 & 2.5 & 2 \\
\hline
\end{tabular}

Table 4: Export of petroleum in billion beery $\mathrm{c} / \mathrm{m}$

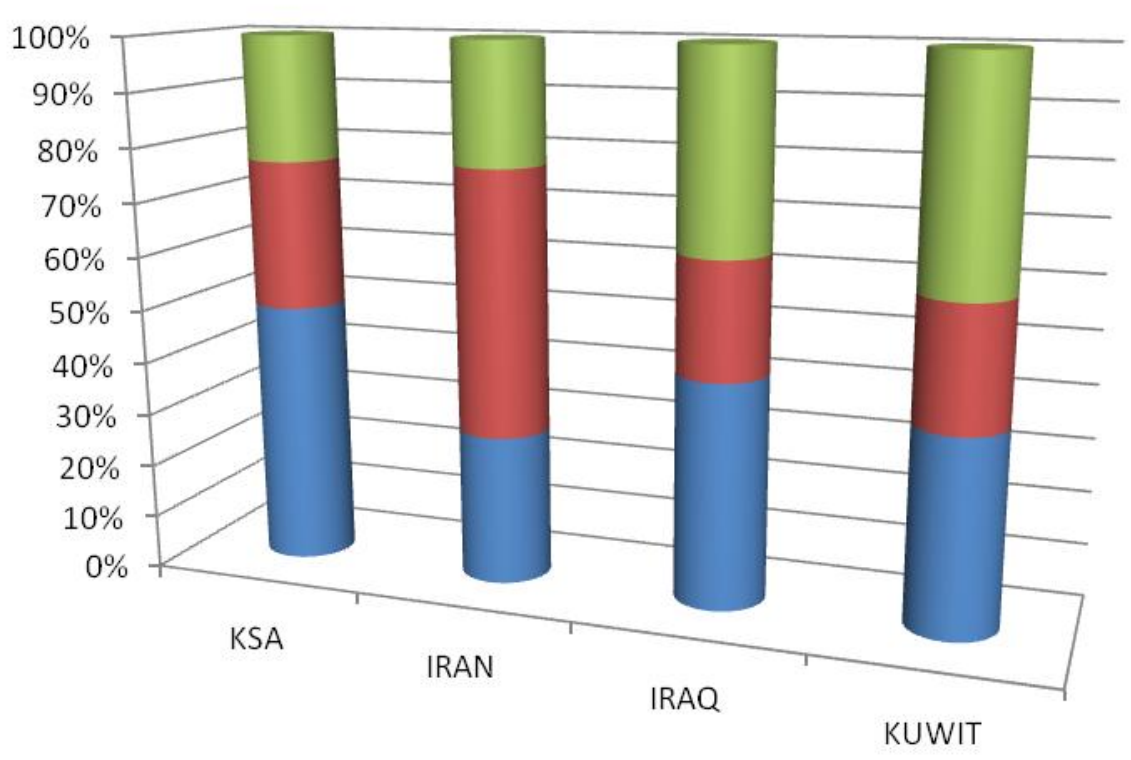




\begin{tabular}{|l|l|l|l|}
\hline Country & Year 1990 & Year 2000 & Year 2010 \\
\hline KSA & 0.5 & 0.3 & 0.2 \\
\hline Iran & 0.3 & 0.4 & 0.5 \\
\hline Iraq & 0.4 & 0.2 & 0.5 \\
\hline Kuwit & 0.03 & 0.065 & 0.075 \\
\hline .A.E U & 0.35 & 0.4 & 0.5 \\
\hline
\end{tabular}

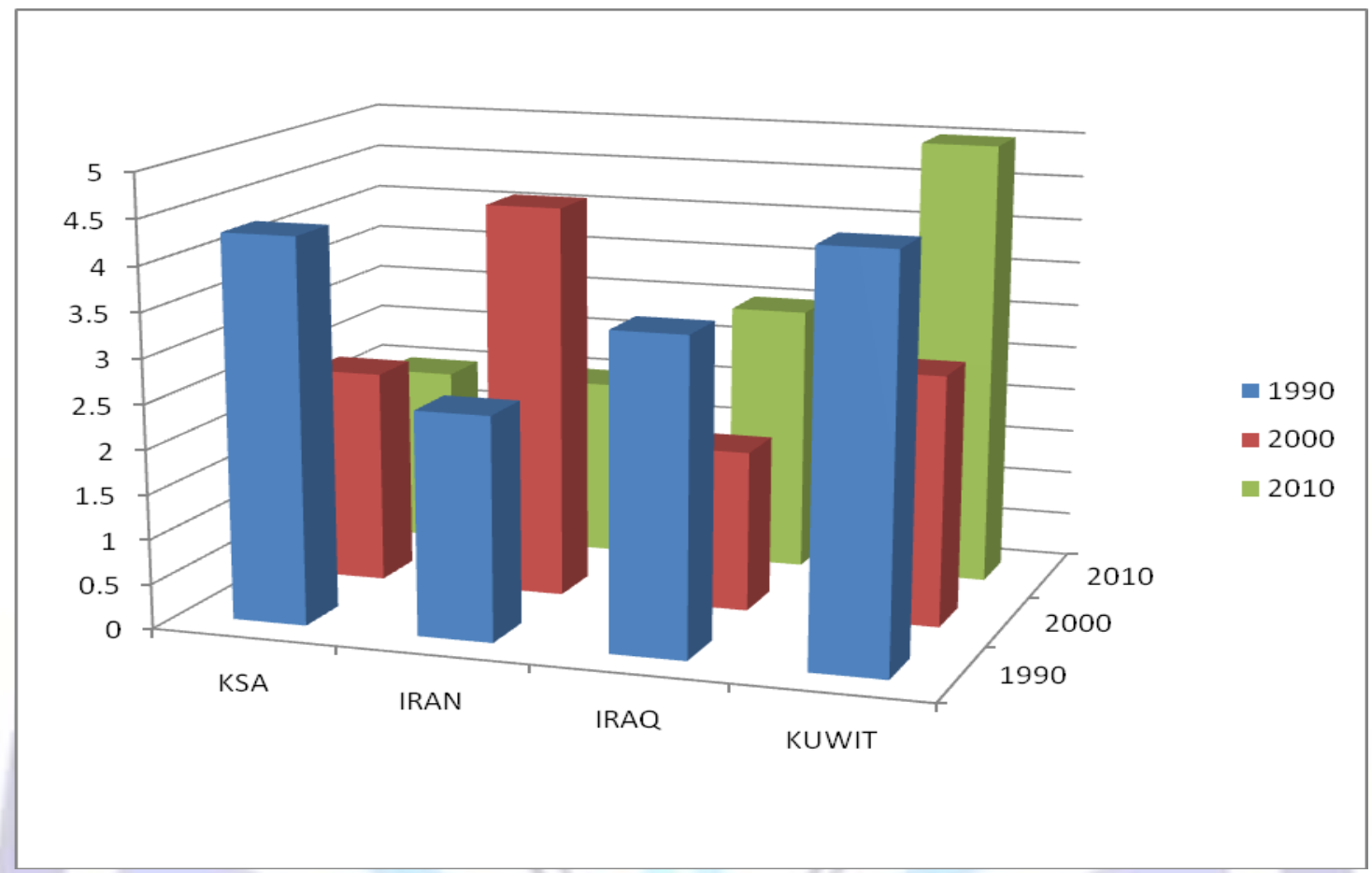

Chart 3 : Show chart of Consumption of petroleum in year 1990,2000,2010.

\section{Results and Outputs}

The results and the out com of the proposed work include :

The present study has covered these issues by using GIS for creation of KSA Land base and the infrastructure specially of water inland, water areas, roads and railroads and exploration and production of petroleum.

GIS is used to analyze the land and the infrastructure on the land of KSA . well as studying the spatial data analysis of the inure like water and petroleum.

The results of this application are very useful for infrastructure planners and the production and explores of oils well using Google earth and GIS for infrastructure services in Saudi Arabia subareas. because they evaluate the level of service provision at the selected area.

It is found that the existing infrastructure of water in land and water area has a big relation with the elevation of Saudi Arabia Subareas.

Geodatabase was build and created using ArcCatelog 9.3 of ESRI GIS software production for KSA Basmap and water and roads infrastructure.

Water dams on water areas was discussed and found that KSA hhs 330 dams for saving water for different purposes in agriculture , human and animals needs.

Rail roads was found on the eastern regions but a new rail road was builds at Makkah Area and Madinah for pilgrim shed Exploration and production of petroleum was shown taking the information from Aramco petroleum company. 
Finally; GIS can be considered part of the decision-support systems for people who formulate and follow infrastructure policy. Also, GIS is a new technology that staffs with GIS training and skills are in high demand in water and oil(petroleum).

\section{CONCLUSIONS}

The main goal of this work was done, creating an infrastructure for planning was created, a challenging field that depends on spatial data such as location and characteristics of water in land, water areas Petroleum and the Rail road to transfer the petroleum production. Infrastructure planners several tasks have been covered to assure that infrastructure services are provided at the best location. Land base (area, subarea and cities) and Infrastructure of water, Petroleum (petroleum ) and railroads. Two important issues was considered in local infrastructure planning. The present study has covered these issues by using GIS for Saudi Arab administrative subareas, infrastructure and neighborhoods cities. Water dams for reserving water was discussed on water areas and water in land taking the information from Ministry of water and electricity web site.

GIS used was applied to analyze the centre catchment as well as studying the spatial data analysis of some diseases such as of blood cancer and blood sugar or fitness patients. The results of this application are very useful for infrastructure planners of water and petroleum demands on a micro-scale and explores the possibilities of using GIS for infrastructure services in Saudi Arabia subareas.. The relation between populations and geographical areas, roads and rail road criteria was taken to help reaching to neighborhood infrastructure. Production especially petroleum production. The same technique can be applied at the other infrastructure activates of other Saudi Arabia subareas . GIS can be considered part of the decision-support systems for people who formulate and follow health policy. Also, GIS is a new technology that staffs with GIS training and skills are in high demand of Water and petroleum in KSA. Finally; GIS can be considered part of the decision-support systems for people who formulate and follow infrastructure policy. Also, GIS is a new technology that staffs with GIS training and skills are in high demand in water and petroleum in KSA

\section{REFERENCES}

[1] Stylus studio, Open Geospatial Consortium, Inc, Whiteside. All Rights Reserved,2009.

[2] AarcGIS teamwater on March 6, 2009, http:ArcGIS TeamWater@esri.com, Building and Maintaining Water Utility Geodatabases.

[3] ESRI, Network Analysis, ESRI, Redlands, 1992.

[4] M. Birkin, G. Clarke, M. Clarke, A. Wilson, Intelligent GIS : Location Decisions and Strategic Planning,

Geo Information, Cambridge, 1996.GIS and Petroleum Industry, Anirban Acharya, Infotech Enterprises

Ltd., Hyderabad, India.

[5] Saudi Aramco. (2009), Saudi Aramco by the Numbers. Available:

http://www.saudiaramco.com/irj/go/km/docs/SaudiAramcoPublic/FactsAndFigures/F\%26F2009/SAbytheNumbers.pdf.

[6] Kevin McLay, Roland Muggli, Safia Mazrui: ArcGIS in the Petroleum and Gas Exploration Workflow ESRI UC 2003 PDO, Muscat, Oman.

[7] GIS Systems/Data Integration Success Guide Richard Salazar, Metropolitan Water District of Southern California, Los Angeles, USA.

[8] F. Al-Shamsam \& N. K. Puripanda(2007) The Use of GIS in Bahrain Petroleum Field Development \& Pipeline Management, BAPCO, Bahrain.

[9] S .K.Ghosh, M.Paul,(2008)A Service Driven Approach for Integration of Heterogeneous Geospatial Data

Repositories Indian Institute of Technology, Kharagpur, India.

[10] Abderrahman, W. a., 2009. Water demand management in Saudi Arabia. (Chapter 6). Book published by International Development Research Centre, Canada.Available at:http://www.idrc.ca/en/ev-93954-201-1DO_TOPIC.html

[11] Abderrahman, W. a., 1997. The Use of Closed Water Cycle in Industrial Plants in Saudi Arabia," in Proceedings of the Conference on Development and Environmental Impact. 21-23 September, Ministry of Municipal and Rural Affairs,

Riyadh.

[12] Al alawi, m. and m. abdulrazzak, 1994. Water in the Arabian Peninsula: Problems and Perspectives," in P. Rogers and P. Lydon (eds.). Water in the Arab World: Perspectives and Progress, Division of Applied Sciences, Harvard University, Cambridge, Mass.

[13] Al-ibrahim, a. a., 1990. Water Use in Saudi Arabia: Problems and Policy Implications. Journal of Water Resources Planning and Management, $116(3): 375-388$. 
[14] Al-tukhais, a. s., 1997. Water Resources and Agricultural Production in Saudi Arabia: Present and Future. Proc. Water Resources and Its Utilization in Saudi Arabia: Proceedings of the First Saudi Conference on Agricultural Sciences, 25- 27 March 1997, College of Agric., King Saud University, Riyadh, KSA.

[15] Brooks, d. b., 2005. An operational definition of water demand management. Submitted to: International Journal of water Resources Development.

[16] Bushnak, a., 1997. Water Desalination and Wastewater Reuse: Review of the Technology, Economics and Applications in the ESCWA Region. Expert Group Meeting on Development of Non-Conventional Water Resources and Appropriate technologies for Groundwater Management in the ESCWA Member Countries. 27-30 October, Manama, Bahrain. Economic and Social Commission of Western Asia (ESCWA)/UN, Beirut.

[17] Dabbagh, a. e. and W. a. abderrahman, 1997. Management of round water Resources under Various Irrigation Water Use Scenarios in Saudi Arabia. Arabian Journal of Science and Engineering 22(special theme issue on water resources in the Arabian Peninsula), pp. 47-64, 1997.

[18] Fao, 1997. Irrigation in the Near East Region in Figures. FAO Country Report Saudi Arabia 9 C. FAO Land and Water Division, Food and Agriculture Organization of the United Nations, Rome 1997.

[19] Fao, 2009. Irrigation in the Middle East Region in Figures AQUASTAT Survey 2008. FAO Water Report 34, Country

Report Saudi Arabia. Edited by Karen Frenken, FAO Land and Water Division, Food and Agriculture Organization of the United Nations, Rome 2009, pp. 325-337.

[20] Imtiaz Ahmed, Dimitris Krinis, Wessam H. Mahmoud, Hamad M. Al-Marri Saudi Aramco Exploration and Producing

(E\&P) Dhahran, 25th Annual ESRI International User Conference (San Diego, July 2005) Saudi Arabia.

[21] Ishaq, a. m. and a. a. Khan, 1997. Recharge of Aquifers with Reclaimed Wastewater: A Case for Saudi Arabia," Arabian journal for Science and Engineering 22, pp. 133-41 (special theme issue on water resources in the Arabian Peninsula).

[22] MaW, 1984. (Ministry of Agriculture and Water), Water Atlas of Saudi Arabia, MAW, Riyadh.

[23] MaW, 1992. (Ministry of Agric. and Water), Agricultural Statistical year Book, Vol. 7, MAW, Department of Economic Studies and Statistics, Riyadh. Kingdom of Saudi Arabia.

[24] U. s. department of energy, 2002. Saudi Arabia: Environmental Issues. Energy Information

Administration.Online:http://www.earthscape.org/r1/ES15071/doe_saudi. html.US Department of Energy, 2002.

[25] Mop, 1990. (Ministry of Planning) Fifth Development Plan, MOP, Riyadh.

[26] Pmsaun, 2009. (Permanent Mission of Saudi Arabia to United Nations). Development and the environment in Saudi Arabia.prepared by permanent mission of Saudi Arabia to United Nations PMSAUN). http://www.un.int/saudiarabia/ch146pln.htm

[27] SiWi, 2009. Water Resources of the Middle East. Background Report to Seminar on Water and Energy Linkages in the Middle East. Stockholm International Water Institute, (SIWI), Sweden.

[28] UunCCd, 2000. Executive Summary. The Third National Report for the Kingdom of Saudi Arabia about the Implementation of the United Nations Convention to Combat Desertification.

[29] Stylus studio, Open Geospatial Consortium, Inc, Whiteside. All Rights Reserved,2009.

[30] AarcGIS teamwater on March 6, 2009. http: ArcGISTeamWater@esri.com, Building and Maintaining Water Utility Geodatabases.

[31] K. H. ZAHARANI, M. SHAyAA AI-SHAyAA and M. B. BAlg " Water Conservation in the Kingdom of saudi Arabia for better environment" Bulgarian Journal of Agricultural Science, 17 (3) 2011, 389- 395

[32] ArcGIS in the Petroleum and Gas Exploration Workflow - ESRI UC 2003. Kevin McLay, Roland Muggli, Safia Mazrui, PDO, Muscat, Oman.

[33] GIS Systems/Data Integration Success Guide Richard Salazar, Metropolitan Water District of Southern California, Los Angeles, 2011, USA.

[34] S.K. Ghosh, M. Paul, A Service Driven Approach for Integration of Heterogeneous Geospatial Data Repositories Indian Institute of Technology, Kharagpur, 2008, India.

[35] U .S.-Saudi Arabian Business Council. (2010) Public-Private Agreements Upgrade Saudi Water Infrastructure. U.S.Saudi Business Brief. 9-10. 
[36] T. Y. Al-Ghasham et al., "Industrial Wastewater Treatment for Reuse, Assessment Study In A Saudi Aramco Facility," Saudi Aramco Journal of Technology, Vol. 7 Fall 2005, pp. 52-60, 2005.

[37] JETRO, "The Study on Wastewater Treatment and Water Reuse in Saudi Aramco, Saudi Arabia," Japan External Trade Organization (JETRO) Water Reuse Promotion Center, Sumitomo Corporation, Riyadh, January 2009.

[38] DIVA-GIS (2001), free simple \& effective, http://www.diva-GIS .org/gData.

\section{Author' biography}

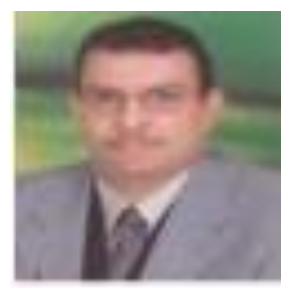

Magdy Shayboub: Was born in El- Menoufia, Egypt, in 1966. He received the B.Sc. degree in Electronic Engineering in 1989, and M.Sc. degree for his work in Computer Science and Engineering in 1998, all from the Faculty of Electronic Engineering, Menoufia University, Egypt. In 2005, he received his Ph. D. in Computer Science from Faculty of Computers and Informatics from Helwan University, Egypt. He is working as an assistant professor of computer science at the Faculty of Computers and Informatics, Suez Canal University, Egypt from 2006 until now. His research interests are in Artificial Intelligent (Al) Applications and Intelligent Agents (IA), Information Retrieval, Computer Networks Security and Semantic Web. Now is working a head of Medical Records Department and computer science in the Faculty of applied Medicine Science in Taif University, Kingdom of Saudi Arabia.

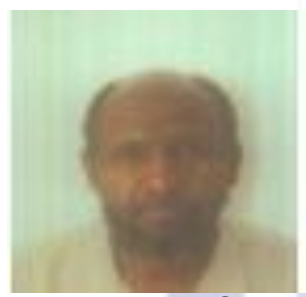

Samir M. Adam: was born in Elfashir , on November 21, 1959.Graduated from U of G Faculty of Science and Technology in 1986 with a B.Sc.degree in Electronics, Instrumentation and applied physics .Graduated from $\mathrm{U}$ of $\mathrm{K}$ faculty of Mathematical Science Department of Computer with a M.Sc Degree in Computer Science 1996 .Ph.D in Computer Science University of Khartoum 2012. Computer programmer in NEC from 1986 until 1994Chief of Computer programmer section NEC from 1990-1994 .Omharaz NEC Computer Training Center manager 1994-1996.Computer teacher , Ministry of Education at Saudi Arabia from 1996 till 1999. Now is working an assistant professor of computer science at the Faculty of applied Medicine in Taif University, Kingdom of Saudi Arabia 